\title{
Loitsud ja rahvaarstid Virumaal
}

\begin{abstract}
Mare Kõiva
Teesid: Virumaa näitel vaadeldakse loitse, millega reguleeriti kommunikatsiooni inimeste ja vaimumaailma vahel ning arstimissõnu. Vormiliselt kirevad arstimissõnad kasutasid palvete, piibli ja lauluraamatute kirjakohti, põhinesid legendilisel ainestikul, allusioonidel ja müütilisel maailmapildil. Artiklis iseloomustatakse a) suulise ja kirjaliku traditsiooni vahekorda loitsutraditsioonis, seoseid fiktsionaalsete ja reaalsete tarkuseraamatutega; b) keelekoodi vahetusi; c) sõnamaagilise käitumise reeglistikku; d) arstimissõnu ning sotsiaalseid suhteid, majapidamist ja loodussuhteid reguleerivaid sõnu.

Artikli teine pool vaatleb muutusi rahvaarstide ravitraditsioonis. Viimase saja aastaga on rahvameditsiini võttestikku integreeritud teadmisi erinevatest koolkondadest, tähtsustusid alternatiiv- ja komplementaarmeditsiini suunad (jooga, hiina meditsiin, ajurveeda, muusikateraapia jm), millest enamik on kosmopoliitsed suunad. Seega saame üldistada, et regionaalse meditsiini kõrvale on astunud kosmopoliitne rahvameditsiin. Teise olulise suunana eendub kohaliku rahvameditsiini tähtsustamine, mis rõhutab põlisväärtusi ja loob kultuurilisi uustõlgendusi. Muutuste iseloomustamiseks tutvustatakse nelja ravijat poolmüütilisest nõidkarjusest kuni meditsiinivõtete ja kohaliku kultuuri uuendajate-ravijateni.
\end{abstract}

Märksõnad: alternatiivmeditsiin, arstimissõnad, kosmopoliitne rahvameditsiin, loits, nõiaraamat, rahvaarst, rahvameditsiin, suuline ja kirjalik pärimus, Virumaa

\section{Sissejuhatus}

Virumaa on tunnistatud rahvaluule ja mütoloogia unikaalsete motiivide tõttu eriliseks piirkonnaks, mida on mõjutanud kontakt- ja naaberkultuurid (Loorits 1932). Usundis on tugevaid mõjutusi lähtunud lisaks veel naabrussuhetest pärimuserikka Harjumaaga, rääkimata idaslaavi kultuuri mõjudest, mis saabusid lähedal asuvast Peterburi linnast ja selle ümbruskonnast ning Virumaal paiknevatest vene ja vanausuliste küladest, hiljem suvitajatelt, samuti lähiümbruskonna sugulasrahvastelt - läänemeresoomlastelt. Virumaa 
ja lähedase Ingerimaa laulukultuuri peeti kogu kuulsa soome-karjala runolaulu ja eesti regilaulu hälliks, sealt pärinevad paralleelid eesti sünnisõnadele (Krohn 1924). Sellisena ei ole Virumaa üksnes unikaalse pärimuse piirkond, motiivide ja usundiliste praksiste ülekandumise ala, vaid ka moodsate kosmopoliitsete rahvameditsiinivõtete ja kontseptsioonide kese.

Artikkel valgustab Virumaa loitsupärimust, vaadeldes lähemalt loitsude struktuurseid erinevusi ja funktsioone. Loitsud ehk nõidussõnad (rahvapärane termin sõnad) olid kirjalikult ja suuliselt levinud tekstid, millel usuti olevat üleloomulik jõud, et mõjutada inimeste vahelisi suhteid, ennetada ja ravida haigusi, edendada töid ja majandustegevust, tõrjuda metsloomade ning loodusnähtuste põhjustatud kahju ja suhelda üleloomulike jõududega. Nõidussõnad kuuluvad sõnamaagia hulka ja olid maagia vanema liigina ümbritsetud kindlatest normidest ja piirangutest sõnade kasutamise ja edasiandmise, aga ka neid saatva rituaalikompleksi kohta. Loitsimise juurde kuuluv tavand oli samuti läbi põimunud rangete usundisüsteemist toetatud nõudmistega, mille juures oli keskne sümbolite ja märkide kasutamine ja usk sõnade mõjuvõimu. Tihedalt seotud usundi ja sotsiokultuurilise kontekstiga, muutusid nõidussõnad koos üldise kultuurisüsteemiga, samas säilisid käsikirjades vanemad kihistused ja sotsiaalsed mudelid vastavate esindustekstidena (vitsasõnad, saksasõnad).

Artikli teine pool esitab ülevaate viimase saja aasta jooksul Virumaa rahvaarstide kohta jäädvustatud teabest. Ravijad integreerisid oma ametiteabesse uusi võtteid erinevatest allikatest, nad olid kaua esimene ja ainus kättesaadav professionaalne abi. Komplementaarmeditsiini raviviisid (siia kuulub rahvapärane ravimine oma mitmekülgsuses) on muutunud ametliku, institutsionaliseeritud meditsiini arengute toel, kusjuures mõjud on olnud vastastikused, kuivõrd süsteemid toimisid sama kultuuri lähedastes sfäärides. Viimasel poolsajandil on Virumaa ahvatlenud meditsiiniabi otsijaid teistest Eesti piirkondadest, ravijate juurde sõideti abilootustega üle kogu Eesti. Põhja-Eesti rahvameditsiin on olnud avatud linnadest lähtunud uuendustele. Mõjulinnadest (Tallinn, Narva, Rakvere) saabus ravijaid seansse andma, ja see tava pole muutunud tänini. Samas ulatusid siia gastroleerivate Peterburi/Leningradi piirkonna ravijate ja selgeltnägijate visiidid. Hilisemal ajal on rändmeedikuid saabunud maakera eri paikadest, Euroopa kõrval Aasiast ja Ameerikast. See lubab viidata, et patsiendid, haiguste käes vaevlejad, kes ei saanud vajalikku diagoosi ja ravi lähiümbrusest, liikusid seda otsides ringi, samuti nagu oma sotsiaalse elu probleemidele lahenduse otsijad. Sama tava oli juurdunud ravijate ja selgeltnägijate seas, kes (eriti viimastel kümnenditel) osalevad globaalses teadmisterändes. Virumaa oli avatud 20. sajandi olulistele esoteerika ja alternatiivmeditsiini koolkondadele, ent see teema jääb artiklis lähemalt käsitlemata. Teises osas iseloomustatakse jäädvustatud pärimuse põhjal pikemalt nelja kohalikku ravijat. 

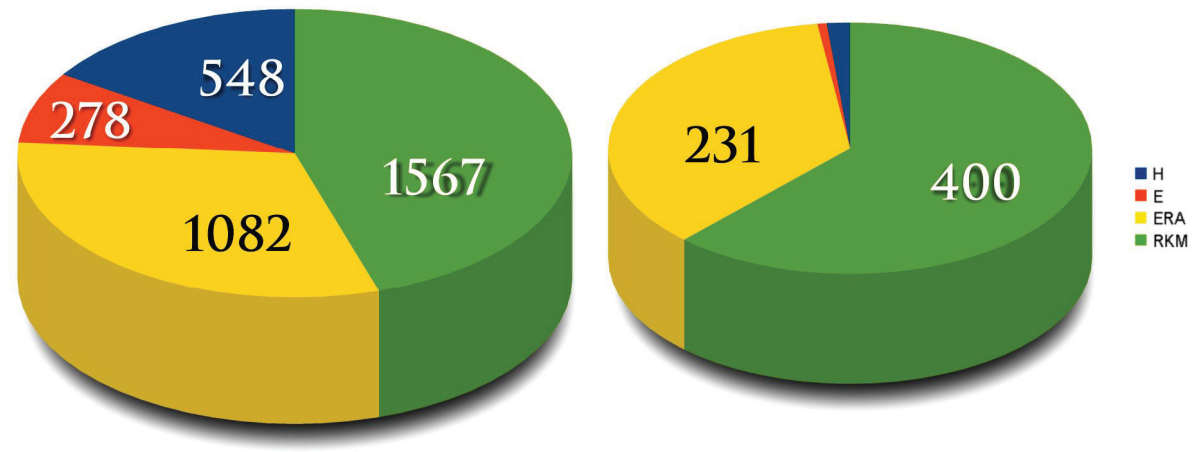

Joonis 1. Nõidussõnu on suuremates rahvaluulearhiivi kogudes (vasakpoolne joonis) rohkem kui teateid ja jutte rahvaarstidest (parempoolne joonis). Erinevuse põhjus peitub kogumistaktikas: juba Jakob Hurt pidas loitse tähtsaks liigiks, rahvaarstid hakkasid uurijatele hiljem huvi pakkuma. See on üks rahvaarste puudutava materjali arvukuse põhjus ERA (1927-1944) ja RKM (1947-1996) käsikirjades.

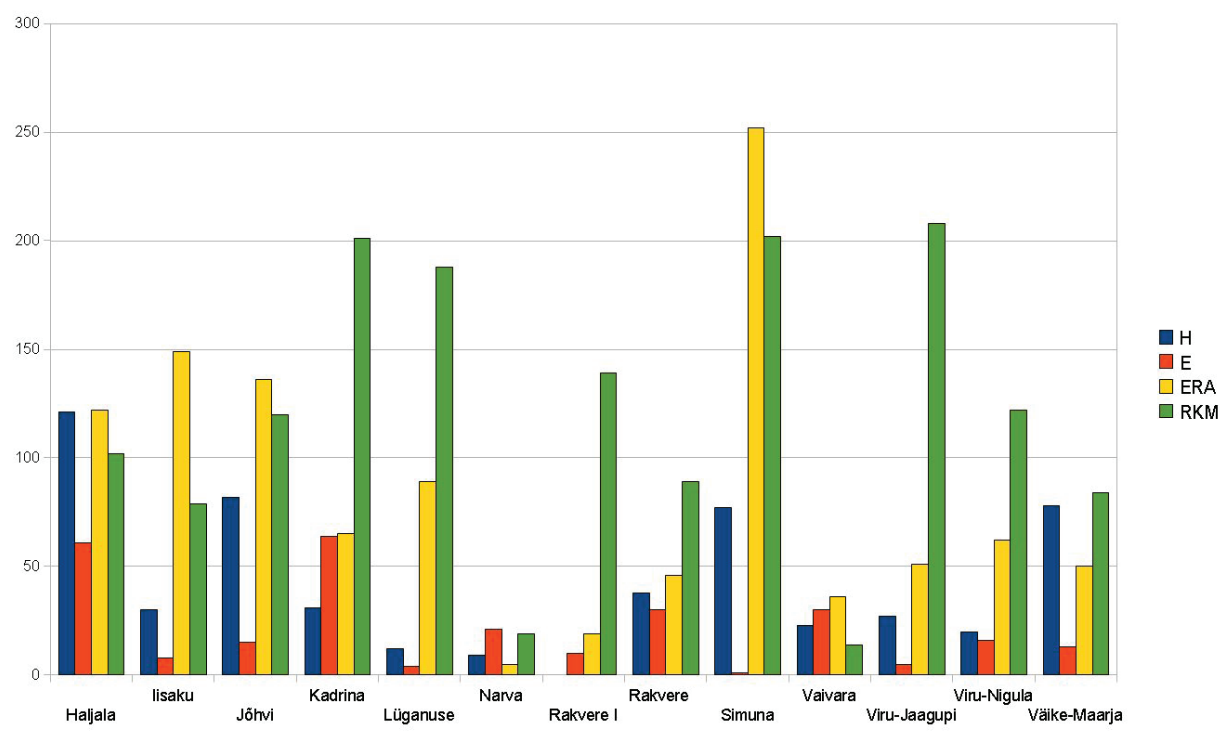

Joonis 2. Rikka pärimusega kihelkonnas oli loitsude kogumine edukas ka 20. sajandil. 


\section{Virumaa loitsud}

\section{Suuline ja kirjalik loitsupärimus}

Loitse kasutati juba vanades kultuurides suuliselt ja kirjalikult ning sama tendents iseloomustab ka eesti nõidussõnu. Tihedam intertekstuaalsus on teine loitsude tunnusjoon: loitsude sisu on seotud müüdimotiividega, kuid tekstid on allusioonide ja assotsiatsioonide kaudu seotud pühakirjaga; piibli ja lauluraamatute kirjakohti ja tekste kasutati loitsuna või laenati neist katkeid loitsuteksti. Arhailiste uskumuste kohaselt on vanad käsikirjad ja raamatud suuremas kokkupuutes pühadusega, sest neis on säilinud algne sõnum. Näiteks usuti, et varasemad lauluraamatute tekstid ja varased piibli väljaanded sisaldavad väekamaid tekste (vrd Wheelock 1987), mistõttu neid hinnati ka loitsudena kõrgemalt.

Vanade liikide puhul põimuvad omavahel tihedalt fiktsioonid, uskumused ja tegelikkus. Väidetavalt loitse sisaldavatest ja vähemalt osalt nende jõul toimivatest raamatutest on tuntum pärimus Kuuendast ja Seitsmendast Moosese raamatust. Piiblisse olevat algselt kuulunud seitse Moosese raamatut ja neist kaks viimast raamatut olevat sisaldanud juutide ja Egiptuse salateadmisi, loitse ja tarkusi, mille Mooses sai Siinai mäel otse jumala käest oma rahva vabastamiseks Egiptuse vaarao vangipõlvest. Pärimus omistab kõiki seitset Moosese raamatut sisaldavale piiblile erilise väljanägemise: see on punase ja mustaga valgele paberile või valge ja punasega mustale (paksule) paberile kirjutatud käsikiri või trükitud raamat. Eesti rahvajuttude järgi olnud seitsmel Moosese raamatul nahk- või puukaaned ja lukk saladuste kaitsmiseks asjasse mittepühendatute eest. Valitsus/mõisnikud/kirikuõpetajad lasknud väärtuslikud piiblid eestlaste käest ära korjata: neid käidud kodudes otsimas, leitud raamatud viidud minema ja hävitatud. Üksnes mõned peidetud eksmplarid jäänud alles, mida kasutatud ravimisel või nõidumisel.

Kui folkloristile meenutab raamatu välimuse kirjeldus keskaegseid majusklitega ilustatud raamatuid ja maagiakäsikirju (Kõiva 2011a, 2011b, 2011c; Cunningham 1999), siis keeleteadlaste arvates on juttudel seoseid tegelike ajaloosündmustega. Nimelt otsis kirjakeele reformija pastor Eduard Ahrens (1803-1863) rahva käest piibli esmatrükke ja võttis mõned neist endaga kaasa. Ahrensit kannustas õpetlaslik huvi piibli leviku vastu, millest sai ärgitust rahvapärane käsitlus tarkuseraamatu eestlaste käest äravõtmisest. Vandenõuteooriaid meenutavad umbkaudu samasse aega kuuluvad uskumusjutud mõisnikest, kes mürgitavad kaevusid või külvavad sinna koolera- ja katkupisikuid eestlastest vabanemiseks (vt Hiiemäe 1997). 
Tõepära on selles loos niipalju, et 1739. aastal trükitud täispiibli osa eksemplare oli varustatud puukaante ja lukuga, mis on vastavuses rahvajutu seletustega. Uskumusjuttude sisu põhjal võib üldistada, et Seitsmes Moosese raamat oli universaalne: temaga sai ravida ja samas põhjustada peaaegu kõiki haigusi, surnuid ellu äratada ja vaimabilisi kutsuda, püssikuul ei tabanud raamatut ega selle omanikku.

Rahvalikel uskumusjuttudel tarkuseraamatust on reaalsusega sidet hoidvaks toeks sajandeid Euroopa ja viimastel sajanditel ka Eesti kultuuriruumis ringelnud trükitud maagiaraamatud, neist mitme tiitlil on kirjas nimetus "Kuues ja Seitsmes Moosese raamat". Mõistetavalt jõudis osa neist algupäraselt võõrkeelsetest ilmumitest rahvalike isetõlkeliste käsikirjadena levida käest kätte. Mainigem, et õigupoolest ilmus 19. sajandi lõpus ja 20. sajandi alguses õhuke maagiaõpetusi ja paari loitsu sisaldav tõlge kahe trükisena ("Kues ja seitsmes Mosese Raamat" 1872, 1914) ning kordustrükina 1990. aastatel ("Must piibel" 1994). Rahvaluuleteadlane Matthias Johann Eisen (1896) esitas esmase kokkuvõtte tarkuseraamatut puudutavatest rahvajuttudest juba 19. sajandi lõpus, mis kuidagi ei kahandanud praktikute huvi. Eestlased on trükisõna usku, ilmunud Moosese raamatust on endale ravisõnu leidnud vähemalt üks rahvaarst (Kõiva 1989).

Rahva fantaasiat kütnud maagiaraamatute ja loitsukäsikirjade juured ulatuvad uus- ja keskajast palju kaugemale - vanimatesse kirjakultuuri piirkondadesse ja sügavale kirja pandud teadmiste kihtidesse (vt Hiina kohta Harper 1997; Mesopotaamia kohta Cunningham 2007 [1997]). Maailma vanimad säilinud loitsud on kirjutatud papüürusele või savitahvlitele ja nad on vähemalt 4500-3500 aastat vanad (Cunningham 2007: 13; Yamauchi 2005). Loitse kirjutati juba tuhandeid aastaid tagasi vastavalt vajadusele ümber ja tõlgiti praktilise vajaduse tõttu ühest keelest teise. Sama vajadus motiveeris tuhandeid aastaid hiljem eestlaste kohmakaid tarbetõlkeid. Ka muistsete loitsude funktsioon (kurja peletamine, arstimine) ja võtted (analoogial ja võrdlustel põhinev rituaal) sarnanevad hilisemate aastatuhandete nõidussõnadele, sh Virumaal kasutatud sõnadele. Meie säilinud loitsukäsikirjade vanus ulatub üksnes 19. sajandi keskpaika ja sel ajal kirjutati sõnu lauluraamatusse, märgiti paberilehtedele, klassikalises mõttes käsikirja moodustavad 24-50 loitsu sisaldavad vihikud.

Vanad juured on ka taevakirjadel - loitse sisaldanud kristlikel pseudograafiatel, needki ulatuvad tuhandete aastate tagusesse minevikku (VanArsdale 1998-2007) , kuid levisid Eestis alates 18. sajandist baltisakslaste vahendusel (Põldmäe 1938: 104). “Taevast langenud” käsikiri sisaldas lisaks neitsi Maarja unenäole ja õnnetute päevade loetelule ettekirjutusi ja õpetusi pühapäeva pühitsemise ja teiste usuküsimuste kohta, samuti valiku kaitsesõnu, mis pidid 
hoidma omanikku relvahaavade, tulekahju ja verejooksu eest või abistama sünnituse kergendamisel. Taevakirjad (ja selle katked) olid sõduritel kaitseeesmärgil kaasas kesk- ja uusajal, Esimeses maailmasõjas oli nende põues või seljakotis kandmine paljude rahvaste kaitsepraktika (vt lähemalt HDA IV: 21 jj, VII:1385). Eestlastel oli kaitsev taevakiri kaasas Esimeses maailmasõjas, samuti Vabadussõjas ja Teises maailmasõjas, küüditatutel asumispaikades ja Nõukogude vangilaagrites, maailma eri paikadesse ümberasunud eestlastel nende kodudes. Siberi-eestlastel, sh Virumaalt väljarännanud asunikel on taevakirjad tänini kasutusel ravimise otstarbel, omanikud on sinna omakäeliselt lisanud arstimissõnu (Korb 2006: 107 jj).

1921. aastal kirjutab Siegfried Lind oma kogumispäevikus:

Rahva seas on usk sõnade avitava mõju sisse praegugi veel väga suur. Sõnaarstidest peavad iseäranis vanemad maainimesed suurt lugu. Sõnaarstid on üle valla, mõned isegi üle kihelkonna tuntud. Paljudel sõduritel on Eesti vabadussõjas sõnad tuleriista eest paberile kirjutatult kaelas olnud, ehk jälle veresõnad igaks juhtumiseks taskuraamatusse kirjutatud, võib olla siin küll rohkem emade soovil ja abil. (E, StK 1, 151 (a) < Pärnumaa (1921).)

Omapärane (ja loitsudele vastanduv) oli taevakirjade levitamisstrateegia - neid soovitati anda ümberkirjutamiseks, ärakirja mõju peeti originaaliga samaväärseks. Eestis on taevakirjadesse lisatud isegi vaimulikke laule.

Rahvaluulearhiivi kogunenud loitsude suulisust on keerukas määrata: neid hakati suulisest kasutusest üles kirjutama ja käsikirjadest kopeerima baltisaksa haritlaste poolt 19. sajandi esimesel poolel, kuid täpsustused esitamisviisi kohta puuduvad. Ilmusid esimesed müütilise pärimuse väljaanded, millest tuntuima, Friedrich Reinhold Kreutzwaldi ja Heinrich Neusi koostatud ja kommenteeritud "Mythische und magische Lieder der Ehsten" (1854) tekstid on autori arendused rahvaluule ainetel. Alles Eesti Rahvaluule Arhiivi rajamisega hakati esitama täpsustavaid küsimusi, ent samas ei puudutanud need kopeeritud käsikirja, neis leiduvate maagiliste märkide kasutamist ja teksti tõlgendamist. Ilmne on, et loitsutekstides sisalduvad sümbolid seovad sõnamaagiat teiste vanemate uskumustega ning eriti arstimissõnad ja osa sotsiaalseid suhteid reguleerivatest vormelitest on ajastuspetsiifilised. Näiteks on arvukalt loitse vanapärase seletusega: äkkhaiguse lendva ravimiseks või peksuvalu vähendamiseks, mille järele otsene vajadus puudus. Lääne-Virumaa kihelkondasid (ilmekate kirjapanekute poolest paistab silma Haljala) iseloomustab loitsutekstide lähedus regilaulule ja läänemeresoome motiivistikule, paiguti ilmneb neis üsna suur sõnamängulisus. Kuna Ida-Virumaa reflekteerib kultuurikontakte läänemeresoome-slaavi lähialadega, siis iseloomustavad sealset traditsiooni keele- ja tavandikoodi vahetused (Kõiva 1992). 


\section{Keelekoodi vahetused}

Mitmekeelsust kohtab rahvaluules laialdaselt, kuid igal liigil on oma spetsiifika keele kasutamise osas. Loitsudes on tundmatus keeles / võõrkeeles teksti esitamine, tähenduseta sõnad tekstis (nt emaks, paks, maks, mis toimivad püha keele elementidena ja lähendavad teksti kõrgemale üleloomulikule sfäärile) ja ühe keelekoodi vahetus teise vastu liigiomane nähtus. See aitas uskumuste kohaselt suhelda teispoolsuse ja kõrgemate jõududega, mütologiseeris teksti ja rõhutas rituaalse konteksti abil tegevuse erilisust.

Keeleteadlane Crystal (1987) tõstis keelevahetuse puhul esile võimalusi: a) spetsiaalse efekti tekitamine, b) suhtlusest nende välja lülitamine, kes keelt ei oska, c) oma hoiakute edastamine, millest arstimissõnade puhul on tähtsal kohal kõik kolm aspekti. Teadaolevalt kasutasid loitsijad kesk-ja varauusajal tervendamisel ladinakeelseid palvetekste (Uuspuu 1938a, 1938b; Kõiva 1990, 2011b, vrd nt leedu materjalis Vaitkevičiene 2008). Moonutatud ladinakeelseid katkeid leidub ka hilistes üleskirjutustes, kus neil on sõnde autoriteeti kasvatav ja erilist efekti loov ülesanne.

\section{Koolejaluu vastu}

Peap vanal kuul peale päävalooja hü̈̈dma üht surnud inimest nimepidi kolm korda ja kääga tõmbama päävaveeru poolt ja koolejaluu peale vajutama nende sõnade ütlemise ajal:

Oh vägede Jehoova, jumala isa, saada see surnu, [nimi] pühavaimu nimel oma surnuluud ära viima. Tule ja vii oma surnuluu ja tõmba kääga ja vajuta koolejaluu peale [nimi] tule ja vii oma surnuluu, [nimi] tule ja vii oma surnuluu. Rein, Kristus, Petrus, Naman, Naman, Jesus, Maria, Jeesus. Jumala see isa, Jumala see poja, Jumala see P[üha] $v$ [aimu] nimel, aamen. (RKM II 22, 528/9 (8) < Jõhvi khk, 1949-1950.)

Muudest sotsiaalkultuurilistest momentidest mõjutab keelekoodi teise keele oskus (pole põhjust tõlkida, on ka sellisena mõistetav) ja samuti humoristlik varjund, mille põhjustab keelte segamine. Omakeelne kõrgema abi palumine ja kaitseväljend võidi keelte kontaktalal asendada võõrkeelsega, nt juhtus see igapäevaste väljenditega nagu Jumal õnnista!, Jumal aidaku!, samuti võidi kasutada loitsu lõpetamisel venekeelset meieisapalvet.

Üks mees Iisakus oli viina võttand, Kubja omad nimetati. Tulid siia küla alla, siin oli heinakuhi, aed ümber. Seltsimees oli ka temaga, tuli ja pakkus 
viina võttada. Tema ütles: “Gospodi blagoslovi! Gospodi blagoslovi!” Siis sai aru, et vana põlend tukk oli käes. Vist ikka saatan oli.

(KKI 20, 553/4 (44) < Iisaku khk, 1955.)

Venekeelse teksti tõlge eesti keelde iseloomustab järgnevat tuntud kütiõnnistuse realisatsiooni, ütlus tagas edu jahikäigul:

"Ei sulge, ei sulevart" (= "ni puha, ni pera"), soovitatakse sellele, kes välja läheb. Mineja ütleb: "Lähen õnne peale jahile, ehk saan prae." See, kes kodu jääb, see soovib aga minejale nii õnne, et: "Ei sulge, ei sulevart!" (KKI 26, 120 (11) < Jõhvi khk, 1957.)

Huviväärsed on segakeelsed tekstid, näiteks valusõnadena kasutatud vene-eesti segakeelsed "Varona variila", milles tegevuslikult kasutati maagilist valu leevendamise võtet - ringide tegemist -, märkimisväärselt on sõrm enne seda suus märjaks tehtud (vanemas kombestikus omistati süljele raviv ja valutustav roll).

Mu mehe ema luges, kui laps nuttis:

Sarooka, varoona

ja kassit variila

ja meie lapse käsi jälle terve!

Tegi esimese sõrme süljega märjaks, hõ̃rus lapse peopesa.

(KKI 24, 104 (8) < Jõhvi khk, 1957.)

Tõlgituna kõlab venekeelne tekstiosa: Harakas, vares, ma putru keetsin...

Kui eri keeleruumides kasutatavad tekstid on sarnased, võidakse paralleelselt kasutada väljendit kord ühes, kord teises keeles. Kirde-Eestis ja Kagu-Eesti setu alal olid kasutusel slaavi kalendrikombed ja loitsud, mida kontaktaladel teati ja järgiti. Ida-Virumaalt on teada selle tava ja sõnade kasutamise juhtumeid kohalike venelaste poolt venekeelsena:

Vaat see oli jälle üks...

Kolmekuninga talvel kiedavad herned, siis veevad välja kuhugi posti peale ja ütlevad: "Maros, maros, pai garoh!” ('pai' seletab - 'kušate'). Et siis parem herned kasvavad teine aasta. See jälle vana komme.

(KKI 20, 574 (89) < Iisaku khk, 1955.)

Sama kommet on paarkümend aastat varem kirja pandud ka eestikeelsena:

Uueaasta laubä üöse kiedeti herni. Viidi õue:

"Külm, säh süe herned, aga ära süe suve!”

(E 81063 (5) < Iisaku khk, 1932.)

Ida-Virumaale välja ulatub ainult Põhja-Eestis tuntud legendiliste värsistatud loitsutüüpide levikuala, millel sõnavara ja mõistestik on soomemõjuline (vt lähe- 
malt Kõiva 2013). Näiteks verejooksu peatamiseks ja roosihaiguse arstimiseks mõeldud "Tüü, türnakask" leksikas on soome sõnu (maidu, tape), Türja merd on Kaarlo Levón seletanud kui Tibeeria merd või koske (Levón 1904). Türna või türja meri esineb ka muudes eesti loitsudes (ERA II 10, 710 (38) < Jüri; E 45739 (3) < Kuusalu). Kosk on rahvaetümoloogia abil muutunud kaseks. Loits ise kujutab endast üht arvukatest Kristuse ristimisel põhinevatest sõnadest, mis on lähtunud arvatavasti soome traditsioonist.

Roosi või elitinga arstimiseks võtta must kuke sulg, kriipsuta sellega haige koha peal ja laula isi:

Tüdi tüdi, türna kaske, tüdi türna jooksemasta maha maidu laskemasta ema piima pirskumasta punane pudenemasta.

(H III 1, 266 ( 7 ) < Jõhvi khk, 1889.)

Läbinisti võõrkeelseid (eeskätt vene, läti, saksa, soome) loitse on fikseeritud ka muudes Eesti piirkondades. Ingerisoome sõnateadjalt Eeva Rittarilt Koeravere külast lindistasin arstimissõnu 1984. aastal, venekeelseid loitse on fikseeritud rohkemaarvuliselt 1930. (ERA, Vene) ja 1950. aastatel (KKI 20 ja KKI 23). Samas eestlastelt kirja pandud tekstid on kuuldeliselt meelde jäetud ja kuna sisu ei mõistetud, siis on tekstides palju keelemoondeid.

\section{Sõnamaagilise käitumise reeglistik}

Uskumus, et õigesti kasutatud sõna aitab, ent kuri silm ja sõna, kadedus, aga ka oskamatu sõnakasutus kahjustab ja hävitab, oli seotud käitumisreeglitega tundlike ja erandlike olukordade puhul. Sõnamaagia olulised normid sedastasid, millal vaikida, millal tõkestada otse näkku ütlemisega, meelitamise, sõimu ja ropendamisega. Näiteks raskesti ravitava ja aeglaselt taanduva roosihaiguse vastu kasutati nii haiguse verbaalset meelitamist kui ka sõimamist. Tähtsal kohal oli peite- ja asendusnimede süsteem, millega pöörduti ohtlike loomade ja kahju ennustavate lindude poole. Vältimaks kahjurite sigimist või püügiplaanide ebaõnnestumist oli keelatud söögi ajal rääkida nt hiirtest, kaladest ja ulukitest, kalastamisel nimetada kalu nimepidi ja võrgukahju vältimiseks rääkida nimetsi suurtest metsloomadest (hunt, rebane, karu; vt lähemalt kalurite sõnatabudest Loorits 1931). Usundireeglistik keelas otsesõnu kiitmise, imestamise, imetlemise, mille mõjul usuti haigestuvat inimesed või kariloomad ja ikalduvat saak. Kiitmine adresseeriti ümber tagasisaatmis- ja tõrjevormelitega. 
Kuri silm ja sõna oli sajandite vältel keskne haiguste ja majanduskahjude põhjus, selle taga usuti olevat kadedus. Kuri silm oli tavaarvamuse kohaselt kaasasündinud omadus, mille ühe aspekti üldistab Haljalast pärit kirjasaatja teade:

Paha silm ehk imestus tuleb teise inimese sõnast, mõttest ja ka silma vaatusest. Kui üks inimene on pahal tunnil sündinud, siis selle inimese mõte, sõna ja vaatus teevad alati paha. Iga pääv peab oma pahad tunnid olema, kell 12 ja 2 öosel ja pääval. (E 5136 (113) < Haljala khk, 1894.)

Kurja silmaga inimese kiitmisi tuli verbaalselt takistada, milleks sobisid keelamine, ümbersuunavad ütlused, sõimamine ja muud lühivormelid.

Mina ise veel kuulsin, kui öeldi: Võtta silm näppu, siis nääd paremini. Ära imesta last ilmaaegu. (RKM II 309, 253 (13b) < Lüganuse khk, 1974.)

Sülitas ütlejale järele, ise pomises: "Too mogomane on minu lapse imetleja! Vahtigu iseennast ja imestagu oma itsi (itsitamist, naermist). Müga teise lapse kallal haugub.” (RKM II 309, 253 (13c) < Lüganuse khk, 1974.)

Sool, tuhk ja hõbevalge (hõbeda kaabe) olid tuntumad haigusi ja kurja silma tõrjuvad ained, sülg hingejõu kandjana sajandeid kasutusel ohutamisel, tõrjumisel ja ravimisel. (Sümboolne kolm korda üle vasaku õla sülgamine kuulub tänapäevalgi ohutamisvõtete hulka.)

Nähes kodu juures halba kuulutavat lindu või looma, kõnetati teda kahju tõkestamiseks peitenimetuste või meelitusvormelitega, otsesõnu nimetamine oli kriitilises olukorras keelatud.

Kui kaarnad nääd, ei tohi millagi mustlind öolda, vaid ikka valgelind. Kui nääd tulema, siis ütle ikka: "Häid sõnumid, valge linnuke!" Kui must ütled, tuleb õnnetust. (E 6825 (1) < Haljala khk, 1889.)

Samal põhjusel teretati hunti kui onu või külameest ja paluti tal pool teed vabaks anda, ussi nimetati Viljandi- ja Võrumaal meelitavalt mõrsjaks.

Ta ütles huntidele: "Mehed, tee pooleks. Pool meile ja pool teile!"

Kui ta nii oli ütelnud, siis hundid läksidki teine teinepoole teed ja vanaeit läks koos oma lapse ja lapsehoidjaga puutumatult mööda.

(RKM II 68, 208/9 (10) < Simuna khk, 1955.)

Teekonna ja tööde alguse kriitiline piir tuli ületada kohaste sõnade teel, samuti tuli soovida töötegijast möödumisel talle jõudu, et tööjätku ega töötegija jõudu mitte ohustada. Reeglina oli vastus kindlavormiline ja kinnitav: "Tarvis" või: "Jõudu tarvis!" 
Tööinimesest möödudes öeldakse talle: “Tere jõudu!” Kes seda ei teinud, sellele karjuti: "Kellaga siga läheb!" (KKI 47, 820 (322) < Jõhvi khk, 1963.)

Toidulaua äärde sattudes sooviti sööjatele: “Jätku leiba!”, millele vastati: “Jätku tarvis!" Mitmes situatsioonis oli töötegija tervitamine keelatud, et tööjärge mitte rikkuda (nt katusepanijat ega kapsaistutajat ei tohtinud tervitada), või tuli kasutada spetsiaalseid vormeleid (kalale ja jahile minnes, seebi-ja õllekeetmisel, pesupesemisel, samuti võitegemisel kasutati erivormeleid ja ümberütlemist). Sellisel juhul vastati teretamisele head soovi tugevdava vormeliga, vahel hoopis tõrjevormeliga. Mõnigi kord arenesid vastustest pikemad sõnamängulised ütlused:

Tuppa sisseastuja tervitus kedrajale: "Kirpu ketrajalle!" ja vastus: "Täid tulijalle turki (takune seelik), sada iga särki, üeksakümmend üeksa iga nüöri (krooge) vahele!"

(RKM II 200, 716/7 (13) < Lüganuse khk, 1960.)

Sõnamaagia ja sõnamaagilise käitumise jälgi leiame tänasestki kultuurist. Me soovime kalamehele edu sõnadega: "Kivi kotti!" ja autojuhile ohutut sõitu, lausudes: "Nael kummi!" Me eelistame jätta head nägemist, kuulmiseni, homseni, ja väldime kunagi igapäevakultuuri kuulunud jumalagajätmist, mis tänapäeva inimese jaoks märgib lõplikku lahkuminekut. Niisiis tajume kunagist õnnistussoovi "Jumal (olgu) sinuga!" hoopis kui vihjet pika ajalise ja ruumilise vahemaa, kellestki lahkumise või lahutamise kohta.

Mõjusad õnnistused ja edendavad lühivormelid kuulusid igapäevaste, aga ka ainukordsete riituste juurde. Vormeleid kasutati eluetappide piiride ületamisel, nad kuulusid lahutamatult töö alustamise ja esmaohvrite, aga samuti tööde rituaalse lõpetamise juurde. Sümboolsed rituaalid saatsid esimest karja- ja künnipäeva, ternespiima (lehma esmalüps pärast poegimist) tarvitamist, heinateo ja viljalõikuse lõpetamist, vasikate, põrsaste jt noorloomade ohutamist, lambapesemist ja lambaniitu.

Kui lammas saab niidetud, siis piab kolm korda lamba kaela peale sülitama, natuke soola raputama ja ütlema:

"Metsa sööma, merde jooma, mulle uue villa tooma."

(EÜS VII, 378/9 (68) < Kadrina khk, 1910.)

Ternespiimaga seotud mitmekesine normide süsteem määras esmalüpsist osa saama lehma, vasika, aga seejärel koera ja kassi. Vastsündinud vasikaga seotud tavand pidi tagama tervise ja head omadused: vasikat tonksati vastu ahju või tõsteti üles, selle juures sooviti kasvu ja kosumist. 
Kui värskest piimast (ternest) leent keedetakse, antakse kõigepealt koerale ja kassile. Peale söömist lü̈̈akse lusikapõhjaga karjasele tasahiljukesti otsaette ja öoltakse:

"Härg kündma, lehm lüpsma!"

(H II 10, 246 (24) < Kadrina khk, 1888.)

Meie ema, kui keetis esimesest lüpsist ternespiima suppi, sõime puust lusikatega. Kui söönd saime, siis koputasime lusikaga üksteisele pähe ja ütlesime:

"Härg nii vanaks kui Ida, Alma" jne, kuni kõik lauasistujad said nime järel läbi kopputatud. See pidi siis vasika kasvu kaasa aitama. (RKM II 314, 81/2 (3) < Lüganuse khk, 1975.)

Kui lehm piima tuli, siis tuletati ternepiima söömisel meelde, et nü̈̈d tuleb teisele lusikaga otsaette lü̈̈a ja öelda: "See päits on sinu.” [---]

(RKM II 463, 647 (15) < Iisaku khk, 1994.)

Ternespiimasöök oli varem pere maius, ühtlasi tervistav toit, ning ternespiimatooted ja toidulisandid on tänini menukad.

Sõnalise pöördumise vormelid varieerusid vabama sõnastusega ütlustest kinnisvormeliteni.

Kui uusi adrasahku teritatakse, siis peab enne neid kolm korda vastu maad taguma ja ütlema:

“Tõid leiba, too leiba!" Siis toob see ader kündes head viljakasvu.

(H II 9, 82 (14) < Viru-Nigula khk, 1889.)

Vilja puhastamisel sõkaldest kutsuti imiteerivalt tuult:

Kui vilja sarjati, siis minu isa tegi "fuu, fuu" - puhkus niimoodi, et "tule, tule, tuulekene". Niimoodi ütles ja siis puhkus, et tuleks tuul.

(RKM II 370, 122 (10) < Viru-Jaagupi khk, 1984.)

Uute rõivaste selgapanemine ja jalanõude kasutussevõtmine oli oluline sündmus, pisiriitust saatev lühivormel tagas jalanõude ja riiete vastupidavuse. Uute pastelde kohta kirjutab üks Jakob Hurda vähestest naiskirjasaatjatest järgmist:

Kui uued paslad esimest kord jalga panna, siis tantsita paekivi peal ehk muu sileda kivi peal ja ööldakse sealjuures:

Pae paksused, kivi kovadused, ühed paslad, üheksad paelad.

Siis peavad paslad kulumise vastu hästi kovad olema.

(H III 2, 35 (1) < Haljala khk, 1889.) 
Hügieeni ja tervisekombestiku seisukohast oli tähtsal kohal saun - keskne ravimispaik, vanas traditsioonis vaimolendite elu- ja kohtamispaik. Saunakultuur säilis oma rikkuses hilisajani, osa selle juurde kuuluvaid kombeid on tänapäeval taasjuurutamisel. Saunakultuuri osana püsisid pikalt tavandis sauna teretamine, saunatänu ja vormelid, millega saunalised õnnistasid leili ja abi eest, näiteks lastele sooviti tänuks kergeid jalgu ja selgeid silmi jm. Saunasõnades tänati kõiki vihtlejatest saunaehitajani.
Aituma haoraijujale, aituma ahjuküttäjale, aituma vievedäjale, aituma vihtlejale, aituma, aituma, aituma, aituma Aidu jumalale, Uniküla omale hundisitta!
Ise vihtles, ise luges.

(RKM II 230, 506 (86) < Lüganuse khk, 1967.)

\section{Arstimissõnad}

Arhailistest haiguse etioloogiatest püsis pikalt käibel seletus, et tõved pärinevat maast, veest, tuulest, tulest, saunast, kuid ka haigusvaimudelt; haigus võis olla jumala poolt määratud, olulisel kohal oli teise inimese põhjustatud haigus. Levinud seletusviis seostas haiguse veel mõistega viha (algselt roheline, ebapuhas, kibe, mürk, vaen, samuti haiguse alge), mida omistati paljudele elus- ja elututele olenditele. Viha alla sattumine põhjustas sotsiaalse ebaõnne, kuid vihaga kokkupuutesse sattumine või viha sattumine organismi põhjustas põletikke ja haigusi. Viha omistati peale inimeste veel mullale/maale, õllele, piimale, lõngale ja paljudele muudele objektidele.

Haigusi saadeti ära samuti tuule, vee ja tulega, kanti tagasi maapinnale, kurja soovinud isikule või haiguse põhjustanud loomale - st saadeti tagasi lähtekohta. Haigusi sai kanda üle loodusobjektidele, kasutades sõnu ja ohvriande, jättes sinna haige koha pesuvett, haiguskoldega kokkupuutes olnud esemeid, hõbedakaabet jm. Sellistes pöördumistes kirjeldati haigust arengu- ja liikumisvõimetuna, loodi võimatusele rajatud võrdluspilte müütilise maailmaga, saadeti haigus inimtühja paika, lähtekohta või saatnud isikule.

Sõnu mugandati ja adresseeriti ümber vastavalt vajadusele: vahetati adressaat, kohandati sõnastust, muudeti üksikuid värsse või värsirühmi nii, et need sobiksid konkreetse juhtumiga. Kui inimestel ja loomadel sümptomid ning haiguse kulgemine sarnanesid, arstiti neid ühesuguste võtete, ainete ja 
loitsudega. Kuna arstimisriituse käigus vahetati abivahendeid ja muudeti tegevust, siis väiksemate muganduste abil muudeti sõnad kõlblikeks ja riitusele vastavaks. Arstimissõnad oli tavaks lõpetada ehk sulgeda, selleks sobisid vormel Isa, Poja ja Pühavaimu nimel!, aamen ja meieisapalve.

Endisaegsed haigusnimetused olid üldistused, nimetuse taga peitub tänapäevases mõistes rida haigusi, mis võisid mõne tunnuse poolest sarnaneda, neil võis olla oletuslikult sarnane algupära, nad hõlmasid keha kindlat piirkonda. Selle tõttu on rahvameditsiinis haigusnimetusi vähem kui nüüdisaja meditsiinipraktikas. Nimetuste ja seletusviiside sarnasuse tõttu võis rakendada üldisi sarnaseid ravivõtteid ja ravimeid. Näiteks koondusid äkksurm ja -haigused termini alla lendva (lendaja, lendav rabandus, lendvarabandus, rabandus, $\ddot{a} k i(l i) n e)$. Lendva põhjuseks peeti nõianoolt või pahatahtlikku soovi, millega saadeti võõrale loomale või inimesele haigus. Üldtermini lendav alla koondusid rasked südamehaigused, insult, lumbaago, loomade puhitus, äkksurm jm haigused. Erinevaid loitsutüüpe lendva arstimiseks tunti üle kuuekümne, nende sisu ulatus eksortsismisõnadest palvete, haiguse minemakihutamisvormelite, lauluraamatu- ja piiblikatketeni, erinevas vormis tõrjesõnadeni. Ka reuma (varasema nimetusega jooksva) oli üldnimi reumaatiliste vaevuste ja haiguste määratlemiseks ning ravimiseks. Loitsudena kasutati taas tekste, mis sobisid valu leevendamiseks, mitmed olid seotud piibli kirjakohtadega. Nari ehk rodi (randmeliigese põletik, käerandme paistetanud sooned hakkavad rodisema) tekkis rahvapärase arvamuse kohaselt lihaste üleväsimuse ja raske töö tõttu. Nari lasti tervenemiseks sümboolselt närida esimesel lapsel (või pojal), haiguse peale tuli närimise ajal õriseda koera moodi, rannet triikida, kanda lõnga ümber randme - et nimetada mõningaid ravivõtteid.

Kui nari käes on, siis peab vanemate esimene poeg närima ja peale sülitama, üteldes:

Närin nari, närin nari,

mene metsa mättase,

aga mitte inimestesse.

(H II 53, 338 (2) < Rakvere khk, 1895.)

Kooljaluu (luu- või kõhre paksend) tekkis nii loomadel kui inimesel, ja seda arstis tavaliselt spetsiaalsete oskustega ravija. Kooljaluud püüti surnuga ära saata, abiks oli surnukondiga vajutamine vanakuu ajal. Ka numbrite loendamine kahanevas järjestuses aitas tõbe kaotada.

Kui mina olin poisikene oli minu isal teenijatüdruk. Tema ütles, et vanaema oli temale õpetanud lausumisesõnad, kui juhtuvad inimesel või loomal kasvama külge krämbmunad ehk nü̈̈dse aja järele kooljaluu. See on selle vastus: loe sõnad ja hõõru käega haiget kohta. 
Kulu kui kulu, kao kui kaste, mine kokko kui kasetohi.

Kümme, öheksa, kaheksa, seetse, kuus,

viis, neli, kolm, kaks, üht ei ole olemaski.

Minu hobuse jalasääre peale kasvas niisugune muna, ja mina hõerusin käega seda muna, muud abi ei annud tale, aga terveks sai.

(ERA II 199, 256 (6) < Simuna khk, 1938.)

Ohatuse sõnade puhul saadeti haigus eemale, kanti üle metsa, rõhutati võimatuse-vormelitega kadumist:

"Kuivagu, kadugu, soosse, rabasse,

kivi, kannu otsa.

Alt juuritu, pealt ladvatu,

keskelt südametu, päh, päh, päh!”

Ja sülitati peale.

(ERA II 266, 221 (506) < Simuna khk, 1939.)

Haiguste loitsimisel, eriti krooniliste pikaajaliste haiguste ja majapidamistööde juures arvestati kuufaasiga: noorkuu kasvatas, noorendas, ravis, edendas kõike, mis oli nähtaval või maapinnal. Noorkuud teretati nooruslikkuse, hea välimuse, tervise, raha, jõukuse või toidu tagamiseks. Vanakuu kahandas, kahjustas, tõvestas ja rikkus, kuid edendas maaaluseid viljasid; ohtlik oli kuude vaheaeg. Kuuloitsude vanimad üleskirjutused pärinevad 17. sajandist, kuid praegusajalgi aitab kuu vabaneda nahahaigustest ja soolatüügastest, neid ja mitmeid muid nahahaigusi saab kuule üle kanda. Sajatusvormel "Kao kui vanakuu taevast!" lõpetab tihti arstimissõnad, kordus tugevdab nende mõju: Kadogo, kui kuu kadob, hävigo kui kuu hävib (Vaivara khk, 1891).

Soolatüükad. Täiskuu ajal minna kuuri või hoone varju ja näidata kuule soolatü̈̈kaid ja ütelda: "Näe, mis siin on, võta need omale." Kolm korda. (RKM II 159, 37 (5) < Haljala khk, 1963.)

Tuulest saadud haigusi raviti tuule abil; tuulepöörajad ja -vaigistajad, tuulesõnade teadjad on olnud sajandeid hinnatud isikud. Tuult peeti silmahaiguste tekitajaks mustuse, suitsu ja taburikkumiste kõrval (pesuvette sülgamine, haigete silmadega inimese jälgimine, menstruatsioonivere silmitsemine jm). Haigusetekitajaks võis olla voolav vesi, loom (nt madu, kelle nägemine raseduse ajal kandus imikule üle ussitõvena) või nõidus. Raviks tuli silmi pesta silmaallika veega, asetada silmadele taimekompress või kasutada maagilisi 
esemeid ja loitse. Järgnevas tekstis on tõrjumisel olulised põhjapoolne mätas, hõbedakaabe, leotis ja sõnad.

Kui silmad on haiged, siis võta põhja poolt aia äärest tugiteiba alt üks mätas ja kaabi raha küljest puru sinna peale. Siis hauta silmi leotisega ja ütle: "Valgus maale, tervis silmadele!" Vii mätas sinna tagasi sedamoodi, kui ta sealt võeti.

(H III 2, 90 (3) < Haljala khk, 1889.)

Teenekas emakeeleõpetaja Eduard Leppik on kirjutanud päris 20. sajandi lõpus üles silmapesemissõnad, milles pöördutakse tervise saamiseks veevaimude poole.

\section{Silmade pesemine}

Kui võõra koha pääl silmi [= nägu] pesti jooksja vee sees, siss peseja ütleb:

"Attuma, veeisake,

attuma, vee-emake,

võta mu haiguseke vastu,

anna mu terviseke kätte."

Kui nõnda ütelti, siss ei hakkava säält midagi haigust.

(RKM II 381, 326/7 (81) < Kadrina khk, 1985.)

Arstimiseks kasutati veel dialoogloitse, mis kujutavad endast vanimat arstimisviisi, dialoogi arsti ja haiguse tekitaja vahel, mida saadab maagiline tegevus. Kahekõne vahendusel saab haigusetekitaja sõnumi, et ta peab lahkuma. Virumaal on dialoogloitsudega arstitud nari, ööitku (imikute öised nutuhood) ja kaasasündinud lastehaigustest nn koeratõbe. Viimane on üks paljudest haigustest, mis kandus lapsele üle raseduse ajal ehmatamisest. Koeratõves laps oli isutu ja kõhn, teda arstiti näiteks haukumise, lapse sümboolse kaalumise, jahvekivil jahvatamise ja muude võtetega. Virumaal, osas Lõuna-Eesti kihelkondadest, Soomes, Lätis ja Leedus on dialoogloitsu tekst tihti kolmeosaline: küsimusele ja vastusele järgneb kinnitus (arstimine või tõrjumine palutakse lõplikult mõjuda). Näitetekstidest esimeses viheldakse koeratõbist dialoogi saatel koera sabaga:

Kui veikesel lapsel koerataud on, siis saab ahi soojaks köetud ja laps ahjule viidud ja musta koera sabaga viheldud, ja üks jooseb siis kolm korda ümmer maja ja iga korral, kui ring täis on, siis haugub koera moodi kolm korda: Auh! Auh! ja sie, kis last vihtleb küsib: "Mis sa haugud?" ja haukuja vastab: "Ma haugun musta koera tõbe." Siis piab laps sest tõbest lahti saama.

(H II 37, 701 (11) < Jõhvi khk, 1892.) 
Teises toimub haiguse sümboolne jahvatamine:

Kui lapse kõht haige on, peavad kolm leske naest last jahvatama, see sünnib järgmisel kombel: Üks lesknaene võttab lapse, paneb käsikivi peale ja hoiab kinni, teine keerab kivisid, ja kolmas küsib üle ukse:

"Mis sa javad?"

Javaja vastab: "Javan koerataudi."

Küsija ütleb: “Java nenda, et terveks saab.”

Teine vastab: “Javan jah nenda, et terveks saab."

Nenda peavad need kolm leske naest kolmel neljapäeva õhtul tegema.

(H II 7, 638 (18) < Jõhvi khk, 1889.)

Maagilist tegevust tuli enamasti sooritada kindel arv kordi (eelmiste näidete puhul oli tähtis tegevuse sooritamine kolm korda), arvumaagiale ja numbrite loendamisele oli üles ehitatud mitmeid sõnu. Üle-eestiliselt oli tuntud numbrite loendamine ühest üheksani või üheksast üheni maagilise rituaali saatel, mis oli kasutusel ka Virumaal. Osa nõidussõnu põhines kahel paralleelsel arvude real: üks neist (haiguse arvurida) kahaneb, teine (patsiendi rida) kasvab. Virumaal on põhikuju järgmine:

Pistuse sõnad! Lugeda sibula piale ja sibul ära sü̈̈a.

Sina, pistus, torkasid minuda ühe kõrra, mina torkan, pistus, sinuda kaks kõrda.

Sina, pistus, torkasidminuda kaks kõrda, mina torkan sinuda kolm kõrda.

Sina, pistus, torkasid minuda kolm kõrda, mina, pistus, torkan sinuda neli kõrda.

Nii edasi kuni kümneni. Sibulat piab sel ajal terava nuaõtsaga torkima. (ERA II 166, 237 (7) < Iisaku khk, 1937.)

\section{Palved. Tähtvormelid. Legendid}

Loitsudesse jumalanimede, pühade sõnade (piibliväljendid) ja võõrkeelsete üksikväljendite põimimisega muudeti teksti tähendust. Arstimiseks kasutati (jumala)nimesid nagu Elochim, Adonai, Aadam, Abraxas, samuti lühendeid (Abracadabra), piiblist pärit kinnisväljendeid (Jeesuse viimased sõnad), mis toimivad oma olemusliku pühadusega. Samuti olid loitsu funktsioonis kasutusel teatavad piibli kirjakohad ja lauluraamatute laulud (Kõiva 1990, 1998). Kõigi haiguste ja õnnetuste korral oli abi meieisapalvest, mida tarvitati arstimisriituses alustamisel ja/või lõpetamisel. 
Eelnevatele lähedased olid tähtvormelid - kirjalikud müstilise taustaga loitsud, mis põhinesid kabalistikal ja kujutasid endast palve või kindla väljendi lühendit või palindroome, nagu nt roosi- ja tulekahju vastusõnadena kasutatud SATOR-palindroom. Selliste sõnade juures oli oluline graafiline kujundus, tekstile lisati maagilisi märke.

Roosi arstimine oli roosisõnadega. Kirjutati sinise paberi peale OPERA ROTAS TENET. See pidi eesti keeles tähendama: "Metsas hoiab karja." Pidi olema vanas keeles. Mässiti see roosi ümber. Kirjutati nii, et sai lugeda ülevalt alla ühtemoodi:

SATOR

$A R E P O$

TENET

OPERA

ROTAS

(RKM II 251, 623 (40) < Kadrina khk, 1970.)

Paljude loitsumotiivide vanus ulatub mitme tuhande aastani. Kristliku tagapõhjaga loitsutraditsioon eksisteeris kõrvuti katoliiklike palvete, õnnistamistavade ja eksortsismiriitustega. Nelja luterliku sajandi mõjul tekkis omanäoline sulam, kus võrreldes katoliiklike maadega on vähe legendilisi loitse ja pühakute poole pöördumisi. Arvestatav osa Euroopa valuvaigistamis- ja arstimissõnadest põhines keskajast alates Jeesuse elukäigu seikadel ja tema kannatustel; sama iseloomustab ka Eesti pärimust. Meenutagem siinjuures kirjeldavalt legendide ja müüdikatketega ravisõnu.

Verejooksu peatamine oli jõukohane osale loitsijatest ja selle ameti pidajate suhtes kehtisid kindlad reeglid: veresõnade omanik ei tohtinud olla sünnitamise ega loomatapmise juures - muidu jäi veri seisma, samuti keelati õlleteo või lüpsmise juures viibimist - õlu ja piim omandasid vere maitse. Suurem osa veresõnadest olid rahvusvaheliselt tuntud, kasutati ka konkreetsete kirikulaulude kindlaid katkeid või terviklaule. Loitsudes on palju allusioone, nt palutakse verel seisma jääda, nagu seisis Jeesus, kui Johannes teda Jordani jões ristis.

Minu oma lapsepõlve peigmees õpetas veresõnad. Veri jääb kinni ja ravva valu jääb ära. Veri on kuhjas, aga tarretab kõik üles senna. Näid tuleb 9 korda lugeda: "Mina rauda purema, veri vällä tirtsti. Issa, Poiga, Pühavaim. Vesi juosku, veri seisku nii kui Jordani jõõs paas. Aamen. Issa Poiga Pühavaim (3 k.) Aamen. (RKM II 14, 67 (159) < Jõhvi khk, 1947.)

Veresoon kokku, verest saan jägu. Kuidas meie kallis Õnnistegija seisis, kui Johannes teda ristis. See Jumala, isa, poja, pühavaimu nimel. Aamen, aamen, aamen. (ERA II 28, 287/8 (33) < Lüganuse khk, 1930.) 
Ka meenutatakse Jeesuse viibimist Kolgatal, tema ristilöömist, vermeid, mis ristil ei veritsenud. Ristimismotiiv on tihti lühenenud vihjeks, mis põhineb üldtuntud sümbolil või legendil.

Haigussõnades on otseste piibli- ja tavareaaliate kõrval olulised loitsumaailma maastikud, kus tegutsevad inglid, pühakud, Jeesus ja haigusvaimud. Selliste olenditega verbaalselt dialoogi astumine peletas haigusvaimu minema.

Hobusehaiguse vastu

Kolm inglit tulid taevast, käisid korget mäge mööda ja hü̈̈dsid: "Meie lähme rabandust ära võtma ehk äkilist haigust aitama ja kurjavaimu kavalust rikkuma."

"Minge, minge, ma tahan teile abi saata, esiteks homiku, teiseks õhtu, kolmandamaks lõuna [poolt].”

Neid sanu loetaks kolm kord läbi. Iga korra viimaste sanade ütlemise ajal tehakse vassak käe nimetissõrmega hobuselle annetava leiva peale kolm risti ja loetaks issameie ühe hingetõmbamisega ära.

(H III 2, 52/3 (3) < Haljala khk, 1889.)

Loitsumaastikuks võib olla meri (must meri), millest tõuseb mustades riietes must mees - haiguse ja kurjuse kehastus. Must mees võidakse saata metsa, kust ta ei pääse välja. Virumaa tulesõnades tõuseb merest valge mees valge katlaga, tekst on olemuselt lähedane Kuusalu pikematele tulesõnadele. Valge või punane (= ilus) on idaslaavi nõidussõnades sage haigusvaimu tunnusepiteet, võimalik, et see oli meelitus, nagu järgnevates tulesõnades võiks valge mees olla jahutaja, jäise külma võrdluskuvand.

Kolm korda põlenud haava peale lugeda, siis kaob valu ära:

Valge mies tõuseb meresta,

valge kattela käässä,

valge kepp oli kattelassa.

Ära puudu punakivisse,

liha, luisse, liigetesse.

(H III 12, 237 (2) < Haljala khk, 1891.)

Tulesõnades on kristlikud motiivid taas sagedased: haavu oodatakse ravima Maarjat, tuntum kasutatud piiblimotiiv on "Kolm meest tuleahjus" ja neli neitsit (neid on samastatud muistsete saatusejumalustega), kes tulevad oma kinnaste ja sõbaga tulevalu jahutama. Tule poole pöördudes meenutatakse talle, et ollakse tule tuttav - seega ei saa ta sugulast põletada.

Ei tuli minu põleta, mina tule tuttavaida.

Ei suitsu minu sureta, 
mina suitsu sugulane.

Ei vesi minu uputa, mina vee vennanaine.

(E $11579(1)<$ Haljala khk, 1897.)

Sama põhimõte kajastub teistes loitsudes, nt maa-aluseid (nn maast saadud nahahaigus, allergia) ennetavates sõnades:

Kui inimene kuskil maas on istund ehk magand ja tahab, et maasthaigus tema külge ei hakka, siis peab ta ütlema: "Muld, ära tee mullale kurja," ja selle järel sülitama kolm kor[da].

(H III 2, 37/8 (10) < Haljala khk, 1889.)

Inimeste ja loomade liigeste nihestuste ja teiste traumade ravimine oli loitsijate oluline ülesanne. Erinevaid nikastussõnu on kirja pandud üle neljakümne tüübi, sajad kirjapanekud osutavad teema aktuaalsusele. Nikastusearstide ja luude paikapanijate oskusteabe hulka kuulus nikastuslõnga valmistamine värvimata lõngast: selja taga heideti lõnga üheksa silmust, valmistamist ei tohtinud patsient näha.

Nikastuselõng tehti musta lamba, veel parem oina villast. See ei tohtinud olla värvitud lõng. Sellele lõngale tehti üheksa sõlme sisse, nii et nad tõmmati kõik ühekorraga kokku. Kui sõlmed kokku tõmmati, siis lausuti:

Luu luu ligi, liige liike ligi. Liigeta, liigeta.

(RKM II 336, 258 (19) < Väike-Maarja khk, 1979.)

Nikastust raviti lauluraamatutekstidega, numbrite tagurpidi üheksast üheni lugemise, tähtvormelite ja muude nõidussõnadega. Euroopa vanim tüüp "Jeesus kirikuteel" (tuntud veel nimetustega "Merseburgi 2. nõidussõnad" ja "Luu luuga") levib alates 9. sajandist, vanimas tekstis on teelisteks jumalad Odin ja Wodan, kes aja jooksul on asendunud kristlike tegelastega. Näiteks Rootsis on loitsutegelane hobuste kaitsja püha Stefanus - nikastusesõnu kasutati nii inimeste kui ka hobuste abistamiseks. Ka Eesti pärimuses kasutatakse sõnu universaalselt nii inimeste kui ka loomade arstimiseks. Eestis on teelised harilikult Jeesus Peetruse või Maarjaga. Loitsu tüüptegevus kirjeldab Jeesust (koos kaaslasega) rändamas mägedes, kõrbes või üle silla. Jeesuse hobune ehmatab, nikastab jala ja Jeesus loeb parandamiseks sõnad: Luu luuga, nahk nahaga-jalg terveks.

Järgnevad tekstid näitavad võimalusi sama süžee erinevateks arendusteks (üks üleskirjutustest esindab 19., teine 20. sajandit), aga ka seda kuidas tekst võib sisaldada saatva rituaali kirjeldust. Tegevus kulgeb põhiliini mööda, ent kummaski loitsutekstis ei loe Jeesus sooni ja luid siduvat vormelit, vaid tema tegevust kirjeldatakse puhuma ja lausuma, / liikmeid kokku liikmema. Tekstist 
ilmneb, et ta teotseb veel sõnatud punase ja sinise lõngaga, mille asetab kivi alla, maailma, kus ei paista päike ega ole elu.

Kui keski on jala nikastanud, siis peab järgmisi sõnu pruukima:

"Hakkas Jeesus minema.

Jeesus läks teeda mööda.

Maarja läks maada mööda,

hakkas metsas pü̈̈d püüdma,

hobune ehmatas ära, nikastas oma jala.

Jeesus ratsalt maha,

puhuma ja lausuma,

liikmeid kokku liikmema,

sooni kokku sõlmema.

Puhun ma punase lõnga,

sidun sinise sõlme,

panen maha karvalist,

võttan maast havi selga,

havi hammas nikiline, näkiline.

Kuhu ma panen sind?

Panen sinise kivi alla,

kus päike ei paista

ega ilmas ei sigine. Aamen."

(H III 1, 573 (5) < Iisaku khk, 1889.)

Kui Jeesus hakkas kirikusse minema,

Jeesus läks teed mööda.

Kui tee hakkas metsa pöörama,

Jeesuse eesel ehmatas ära ja nikastas oma jala.

Kui Jeesus maha tuli,

hakkas puhuma ja liikmeid kokku lükkima

ja sooned kokku sõlmima.

Võtsin ma punase lõnga,

seon ma sinise sõlme.

Võtan maast, havi selga,

havi, havi, omal nigi-nõgil,

kuhu ma sind panen?

Kas sinise kivi alla,

kus kõik ei paista ega silma ei sigine?

Aamen, aamen, aamen.

(ERA II 28, 286/7 (32) < Lüganuse khk, 1930.) 
Üks tänini aktuaalne ja aktiivne vanema loitsutraditsiooni segment on roosisõnad. Tänapäeval on roosi (vanem nimetus eliting) diagnoosimine lihtne, ent haiguse visa taandumise tõttu on vanad võtted jätkuvalt kasutusel. Rahvapärane seletusviis seostas roosi ehmatamise ja tugevate emotsioonidega ning eristas kolm või üheksa roosi liiki, roosi vorme eristati kas värvi (sinine, valge, punane), päritolu (tuuleroos) või haiguskolde (rinnaroos, luuroos) järgi. Sellise määratluse taga aimuvad erinevad haigused kroonilistest põletikest luutuberkuloosi ja kasvajateni. Roosi iseloomustab väljakannatamatu valu, ühte sellist juhtumit vahendab endiselt Saarde kihelkonna elanikult teeneline eesti keele õpetaja ja kirjasaatja Eduard Leppik:

[---] Tuli olli lõõridesse läinud, suitsu tulli tuba täis, mia hirmusin ära, pannin käe rinna pääle. See külg pastetas kohe üles. Nõnda kui tuli põletas valu sees. Ükski rohi es aita. Siss olli seoke asi. Teise majas olli ka väike laps. Sinna olli tulnud üks vana inimene seda last vaatama [= katsikule]. See olli roosiarst. Mia ollin särgis, üks inimene tulli sisse ja küsse, kas siin majas on haige inimene, Mina siss ütlesin: "Mina see olen.” Tulli siss minu juure. Siss rääkisin temale ära oma haiguse. Tema ütel: “Too mulle köögist üks laasitäis vett.” Siss võttis selle laasitäie vett ja heitis põlvili miu sängi jalutse taha maha. Siss temal olli see laas käes, luges tasa. Kümme-viisteisku minutid luges põlvili, siss tulli üles ja ütel:

"Noh, noorik, joo see laasitäis vett ära, mine sängi ja võta tekk üle pää."

Nii kui ma sängi heitsin, nõnda jäin magama. Ja ärkan üles ja es ole naist ja es ole mul valu. Vat need ollid roosisõnad, mis ta sinna laasi pääle luges. Arvata üks tunn aega magasin ja kohe ollin terve. Vaata, kui kanged on sõnad. Nüüd ei ole seda änam. [---]

(RKM II 381, 316/8 (75) < Kadrina khk < Saarde khk, 1984-1985.)

Levinuim ravivahend oli roosipaber (sinine suhkrupeapaber või vihikukaas), kuhu kirjutati sõnad peale, kriipsutati need pliiatsiga üle, lisati maagilised märgid ja asetati õhukindlalt haiguskoldele.

Rahvas räägib (nimelt üks mees, kes Liivimaalt Eestimaale tulnud): Saadjärve mõisaherra parun Prangel (vistist Wrangel) on sõjast ühe Prantsuse kindrali kääst elitingasõnad toonud, need on:

Roosa pilla, soora pilla, allapasoor.

Need saavad paberi peale kirjutatud, üheksa risti ja üheksa punkti juure tehtud ja elitingale peale pandud. Kellelegi ei tohi aga seda kirja enne näidatä ehk lugeda anda.

(H II 53, 539 (789) < Simuna khk, 1895.) 
Erinevaid loitsutüüpe on teada üle saja. Haigust tõrjuti lauluraamatust pärit laulukatkete, piibli kirjakohtadega ("Kolm meest tuleahjus"), Kristuse elukäigu sündmustel põhinevate või muude legendilistel motiividel põhinevate sõnadega ja kõigi muude sõnamaagia pakutud võimalustega. Tuntum tüüp on keskajal tekkinud ja Eestis üheksa redaktsiooniga esindatud "Kolm roosi". Tekst on seevõrra kodunenud, et võib liituda regivärsiliste loitsudega ja teksti variaablust iseloomustab näiteks asjaolu, et erinevaid värvikombinatsioone roosi iseloomustamiseks on fikseeritud üle 30. Ida-Virumaal on enim levinud kombinatsioon valge-sinine-punane. Lühike tekst erineb kihelkonniti ka selle poolest, milliste tegusõnadega vahendatakse kolme roosi käekäiku, kombinatsioonide arv ületab 60 .

Esimene näitetekst on lähedane eksortsismi-vormelitele, mille vahel paikneb kolme roosi motiiv, loitsu lõpetavad sulgemisvormelid.

Mina vannun sind, sina ruajane vaim.

Mine ära sestsinatsest Jeesuse Kristuse ümmardajast ja sulasest.

Jumala Isa, Poja ja Pühavaimu nimel

aamen, aamen, aamen.

Jeesus tuli läbi kõrbe, kolm ruasi oli temal kääs.

Sinine kuivas, punane närtsis, valge kadus uapis ära.

Jumala Isa, Poja, Pühavaimu nimel

aamen, aamen, aamen.

Mina vannun sind sellest päävast, sellest tunnist, sellest minutist saadik.

Jumala Isa, Poja, Pühavaimu nimel, aamen, aamen, aamen.

(ERA II 166, 258/9 (73) < Jõhvi khk, 1937.)

Teine näitetekst on tavapikkusega, selle suleb kinnitusvormel.

Roosisõnad

Jeesus kõndis tieda müöda,

kolm oli ruosida käessa:

ühe ta võttis, teise jättis,

kolmandemaga taga koputas:

Issa, Poja ja Pühavaimu nimel!

(EÜS X, 1468/9 (14) < Haljala khk, 1913.) 


\section{Sotsiaalsed suhted, majandamine, suhted loodusega}

Loitsud olid olulised ka majapidamistööde edendamisel, nende alustamisel ja lõpetamisel, loodusega suhtlemisel, sotsiaalsete suhete korrastamisel. Kahetuse ehk eeldatava kurja silma ja sõna kahju vältimine ja omavahelise käitumise reguleerimine, aga ka näiteks armastuse maagiline taotlemine ja hävitamine olid olulised sõnamaagilised oskused (just viimatinimetatud rituaale kaugeltki iga rahvaarst ette ei võtnud). Eriti 19. sajandi esimesel poolel oli vältimatu saksasõnade (ülemusesõnad) ja kohtusõnade tundmine, arvukalt on üleskirjutusi vitsasõnadest, mida kasutati vihatud ja raske peksukaristuse valu ennetamiseks ning vähendamiseks. Vitsasõnad on ainsad, kus appi kutsutakse kuradit.

Vitsavalu sanad

Kurat kuulus kuningas ilma pääl, rohke rammumees rahva seas.

Tule tuulesta, üle üheksa kiriku, üle viie viinaköögi, üle seitsme suure linna, vii ära vitsavalu.

(H III 2, 373/4 (6) < Haljala khk, 1890.)

Kuigi vajadus vitsasõnade järele kadus pärisorjuse kadumisega (viimased avalikud täiskasvanute peksukaristused leidsid aset 1905. aasta revolutsiooni järel karistusaktsioonide ajal), on neid sõnu kirja pandud kogu 20. sajandi vältel.

Majandusedu, tööde ja isikliku õnne sõnad olid enamjaolt keerukama maagilise kompleksi osa, vastavad sõnad võivad olla ka stereotüüpsed, neid kasutati mitmete olukordade stabiliseerimiseks ja kurjuse tõrjumiseks. Nt parandati rikutud püssi tuntud haiguse ja kurjuse tõrjevormeliga Oma koer kodu / koer üheksa võrra tagasi / koer koju, kutsikas kõrval.

Kui püss on imestatud, et lindu ei tapa, siis suitseta püss kollaokste ja kaetisrohuga, siis pühi ja puhasta püss heaste ära. Siis poeta püss kolm korda ristamisi oma jalgade vahelt läbi ja ütle: “Oma koer kodo tagasi!” (E 6935 (9) < Haljala khk, 1893.)

Lühemad, osalt lauluvormilised loitsud saatsid mets- ja koduloomadega suhtlemist. Neis kajastuvad looma respekteerimine kõrvuti omaniku õiguse taotlemisega, kohtab vanemaid usundikujutelmasid. Hundisõnades pöördutakse tema poole meelitusnimedega, teisalt kutsutakse püha Jüri hunte talitsema uskumuse kohaselt hoiab püha Jüri hunte jüripäevast mihklipäevani valjais ega lase karjale teha kahju, kui teda appi hüüda. Huntidevalitsejast püha Jüri 
on slaavi kultuuriruumi uskumusmotiiv, mida tunnevad ka Balti ja läänemeresoome kontaktalade elanikud (Mencej 2001).

Kui suvel hunt karja hulka tuleb, siis peab karjane hü̈dma: "Püha Jüri! Püha Jüri! Kannusta! Kannusta hunti valjastega!” Siis hunt teeb suu lahti, ei saa looma hammustada. (E 5125 (4) < Haljala khk, 1894.)

Tuntuimas eesti valuvõtmisloitsus kantakse valu üle varesele, harakale ja teistele lindudele, tekst on tänaseni populaarne. Mitmed kunagi olulised sõnad kandusid 20. sajandil karjaste ja laste repertuaari. Laialt oli laste seas tuntud kurgede ja hanede eksitamine, kuid parve segiajamise järel tuli linnud uuesti korda lugeda.

Kui kurekolmnurk läbi läks, siis hü̈̈dsid neile lapsed:

Sega pudru, sega pudru,

lase looka, lase looka.

Kui siis kureparv oma rivist segamine läks, siis rõomustasid lapsed, et kured just nende käsu peale on oma lendu muutnud.

(RKM II 283, 331/2 (5) < Viru-Jaagupi khk, 1971.)

\section{Virumaa rahvaarstid}

\section{Rahvameditsiini globaliseerumise ja kosmopoliitsuse ilmingud}

Rahvameditsiini saame defineerida järgmiselt: rahvapärane arstimispraktika on oma olemuselt universaalne, sinna on integreeritud käepäraseid võtteid oma ajastu ametlikust meditsiinist ja ajastukesksetest trendidest, kasutatakse erinevaid medikamente ning selle praksises säilitavad oma koha end traditsioonis õigustanud võtted. Oluline roll rahvameditsiini kasutustavade kujundamisel on oma ala spetsialistidel, rahvaarstidel, kes juurutavad uuendusi, muudavad vanu teadmisi ajastukohasteks ja säilitavad vanemaid võtteid.

Eelmist sajandit iseloomustas senisest intensiivsem uute teadmiste integreerimine rahvameditsiini võttestikku, aga ka alternatiiv- ja komplementaarmeditsiini harude tähtsustumine. Kultuuri üleilmastumisega levisid Eestisse esoteerilised õpetused, jooga, hiina meditsiin, ajurveeda, muusikateraapia, uudseid taimi kasutav taimravi, õie- ja aroomiteraapia, uutest trendidest lähtuv ravisalvide valmistamine, inimese holistilise külje arendamine jpm. See protsess toob nähtavale üleminekuala, kus rahvameditsiini üldpraksisesse vahendatakse teadmisi ametlikust biomeditsiinist, pluralistlikust alternatiivja komplementaarmeditsiinist. Rahvameditsiini alased teadmised rikastuvad protsessi tulemusena uute mõistete, raviviiside ja medikamentoossete lahen- 
dustega. Samas ei integreerita kõike, vaid osa, ülejäänu eksisteerib iseseiva komplementaarpraktikana. Kosmopoliitne meditsiin (vrd Dunn 1976; Tan 1989) on ametliku institutsionaalse meditsiini tunnusjoon ja seda iseloomustab lääne meditsiiniteabe laialdane levik; samas on põhjust iseloomustada ka tänast rahvameditsiini kosmopoliitsena - paljud suunad on laialt levinud ja moodustavad üleilmseid võrgustikke.

Kommunikatsiooni areng, informatsiooni liikumine ja transpordiolud lubavad koolitusi ja raviseansse viia linnadest maapiirkondadesse, aga võimaldavad ka osaleda linnades toimuvatel üritustel.

Tänapäeva rahvameditsiini kosmopolitiseerumise ja transnatsionaalsuse kõrval ilmneb selgesti kohaliku rahvameditsiini võimalusi tähtsustav tendents, mis rõhutab põlisväärtusi ja loob kultuurilisi uustõlgendusi. Selle tunnistuseks on raviprogrammid, mida reklaamitakse traditsioonilise meditsiini jätkajatena: põlist saunakultuuri õpetavad kursused, taimravi ja tervisliku toitumise koolitused, linnastressist taastumist võimaldavad enesessesüüvimised looduslikes paikades. Samas võib kohaliku põlistraditsioonina väärtustada ka koolitatud meditsiini vanu võtteid. Näiteks tervisekeskuse Harmoonikum blogi reklaamib mitut uue hinnangu saanud vanemat teraapiat: Meil olid energiakanalite mõjutamiseks omad meetodid. Üks neist oli meemassaaž, teine oli Vana-Eesti massaaž ehk soontetasumine ja kolmas on kaaniteraapia (Lill 2017). Märkigem, et vara-, kesk- ja uusaja meditsiinis kasutatud apteegikaanide teraapia naasis Euroopa ravivõttestikku alles 1970. aastatel ja Eestisse 1980. aastatel. Niisiis pole tegemist ei eesti ega vana traditsiooniga. Laias mõistes rahvameditsiinis (väljaspool ametlikku meditsiinidiskursust) toimuvad protsessid on rahvusvaheliste samalaadsete kultuurinähtuste haru ja nende kaudu lülitatud üleilmsetesse tervist toetavatesse meditsiinivõrgustikesse.

Muutumises on olnud ka ravimtaimede kasvatamine, töötlemine ja turustamine. Muutused ei toetu üksnes tehnoloogilistele uuendustele, vaid ka uute taimede toidukultuuri ja herbalistikasse juurutamisele ning taimeteadmiste teistsugusesse kultuuriruumi tõlkimisele. Oluliseks vaimseks keskuseks on näiteks kujunenud Katrin Luke Karepa ravimtaimetalu. Rõhutades taimeväe olulisust, vahendab Katrin Luke Põhja-Eestis ja laiemalt uusi toidutaimi (nt karulauk) ja taimeteavet (uudsed taimesegud omamaistest ja võõrliikidest tee valmistamiseks, kuusevaigu baasil salvid jm). Samuti osaleb ta fütoterapeudina Põlistarkuste ja Rahvaravi Kooli õppeprogrammides.

Liikudes uuematelt trendidelt vanema suunas näeme, et viimase poolsajandi jooksul on Virumaal tegutsenud tunnustatud diagnoosijad, rahvaarstid, arstijad, needuste eemaldajad ja selgeltnägijad. Näiteks elas Virumaal pikemat aega pendeldaja, selgeltnägija ja ravija Veeliks Jalakas (1928-2013), kes sai tuntuks avalike esinemistega loengutel, televisioonis ja ajakirjanduses. 
Jalakas diagnoosis haigusi ja mentaalset seisundit pendli abil - pendeldamine oli 20. sajandi teise poole menukas uuendus. Jalakas arendas oma oskusi maaenergiate otsimiselt inimeses toimuva diagnoosimise suunas (intervjuud ravijatega, problemaatikast lähemalt Kivari 2016). Selgeltnägijate ja arstijate seas oli tuntud Mare Liiv ehk Jõhvi Mare (1940-2013, vt Jõhvi Mare 2009), ent tänasele Virumaale toovad kuulsust Venemaa telesaate "Selgeltnägijate tuleproov" konkursil esimeste sekka tõusnud Ilona Kaldre ja Marilyn Kerro mõlemad on gastroleerinud mitmes riigis.

Üleilmse etniliste usundite ja omakultuuri sümbolite taastamisliikumise tähis Eestis on muinsuskaitseliikumise ja maausuliste eestvedamisel 1990. aastal rajatud mälestusmärk Virumaal 1640. aastal põletatud nõia Kongla Anne austamiseks (Kongla Ann 2006).

Nõiaprotsesside ja kirikuvisitatsioonide protokollide kaudu on võimalik jõuda 17. sajandil tegutsenud rahvaarstide tegevuseni. Ent jätkakem sajanditega, millest arhiivides on sadu jäädvustusi ja mis osutavad, kuidas Põhja-Eestit ja Virumaa piirkonda mõjutas linnakultuur, kust saabus küladesse ennustajaid, hiromante, kaarditarku, hüpnotisööre, massööre ja imearste. Osa neist peatus Kuremäe kloostris, kuhu sõideti vastuvõtule ka väljastpoolt Virumaad. Rändkaupmeeste kõrval rändasid külast külla ametmehed, kes aitasid näiteks hävitada prussakaid. Rakvere linnast käis ümberkaudu putukaid tõrjumas "Prussaka surm" - sellist kirja kandis ta oma kaabulotil.

Mitmed saabujad olid Virumaalt pärit ja tulid tagasi ajutiste ravi- või ennustamisseanssidega, nagu selgeltnägija ja käevaataja Vitsa Mari (liikus ringi, vits käes, millest tulenes tema hüüdnimi). Mari elas Tallinnas ja käis korrapäraselt Virumaal ennustamas.

Ravimisel kasutati märgilisi esemeid, millel oli usundiline, ajalooline või emotsionaalne väärtus. Näiteks olevat Marie Rosenblatt kasutanud arstimisel Tedre Antsu käest saadud ja Türgi sõjast toodud peopesasuurust hõberaha, millelt kaabitud hõbevalget segati süljega, Marie lugenud sõnad sosinal peale (KKI 41, 318 (4) < Kadrina khk, 1964). Rosenblatt kasutas nahahaiguste ravimiseks sümboolset riitust, milles ühendas sõnajõu usundilise teabega süljest kui hingekontsentraadist ja tunnustatud ravivahendist ning lisas universaalselt toimiva hõbeeseme ravivõime. Konkreetse juhtumi puhul lisandus hõberahale ajaloolise eseme autoriteet.

19. sajandi ja 20. sajandi alguse külaravijate hulka kuulusid luudepaikaja ehk nikastuste ravija, kupumoorid ja aadrilaskjad, ämmaemandad ja hambakaksajad. Nikastuste ja traumade ravimise poolest oli tuntud virumaalane Lõetsa Villem (Villem Epner, snd 1881), kes oli isalt õppinud käte tunnetuse abil ravima loomadel ja inimestel luumurde, paigaldama liigeseid ja lihaste venitusi. Nikastust ravisid veel Kriina Mari, Mart Kaasik Maetsmalt, Liisa 
Tammesalu Sahargult, Mihkel Kruut Edivere külast ja paljud teised. Lüganuselt pärit Savala küla mees Jaan Iisküll hüüdnimedega Luupainaja Jaan ja Savala Jaan (kohast lähtuv nimi) oli nii tuntud ja kuulus, et õppinud arstid kaebasid ta kohtusse. Jaanile tehti ametitundmise katsed ja kuna talle tuli tunnistajateks palju tervenenud inimesi, siis tal lubati oma ametit jätkata. Pärimusjuttude järgi oskas Savala Jaan puusaluu paika panna ja purunenud luid lahasesse panna. Tarkused olevat ta õppinud Iisaku vanalt targalt, kelle juures käinud ussihammustusest tekkinud mädanikku ravimas. Mõlemad Jaani pojad õppinud temalt luudepaigaldamise ameti selgeks.

Kupparid ja aadrilaskjad kuulusid enamasti majanduslikult kehvema rahva hulka. Virumaa tuntud laulikutest käis näiteks Viru Mai ehk Krassmanni Mai kuppu panemas ja oskas loomi arstida (KKI 25, 45 (1) < Jõhvi khk, 1957). Hüüdnime Kuitsi Mai sai ta aia otsas "regivirsude" laulmisest, mida kogunenud koerad kuulama. Aadri- ja kupulaskja olid ka laulik Ann Konsa, Tääde Liisa Atsalama külast, Taoli Anne Kantkülast ja teised. Mitmete nime me ei tea - nad olid tuntud ametinime kaudu (Kupu-Kadri, Kupu-Kaarli jt), nii neist kõneldi ja kirjutati, pärisnimi vajus ammu unustusse.

Meenutame siinkohal veel ühte kupparit - Ieva Kuradit, kes oskas rahva arvates tulekahju ajal tuult keerata ja sellega tuld kustutada. Ievast jutustas Maarja Amba, laulik Iisaku kihelkonna Illuka vallast. Maarja Amba oskas ka ise arstida ja teadis unikaalseid nõiasõnu. Tema meenutus Ievast avab lähemalt kupparite elu ja tutvustab nende töövahendeid.

Ieva Kurat oli vanatüdruk, vähe litsivõitu. Jõi pali viina ja tõmbas miestega. [---] Tämäl õli raha alati viina õsta, ta õli kuppar. Käis laialt ringi, sääl Venemaa puol Vihtses käis ja tienis ikke viis kopka sarve päält. Üks nuar poiss ôli Vihtses last kaheksatõistkümme sarve selga panna ja siis hüppand ise jõkke, Vihtse jõkke. Sarved tulled kõik lahti ja kaduned vällä, Ieva oligi sarvidest ilma. Siis katsus kust sai uvved, minagi andasin siit vanu luamasarvi. Ieva lõikas pienikese õtsa maha, pani sinne pääle rakkunahka ehk rasvakelmet ja pistas nõelaga pieni aukusi täis. Õligi uued kupusarved jälle kääs.

Kuppu lassasse paha vere vasta. Kui pia vai kaelasuaned valutavad, vai on juaksev. Kriisa Katri raiub nuaga, sie on valus, aga Ieval õli massin, sellega lõi.

(ERA II 166, 117/8 (32) < Jõhvi khk, 1938.)

Ämmaemanda ametit on raske alahinnata, enamasti tegutsesid selles ametis kohalikud naised, kellest osa oli kursustel mõningast koolitust saanud ja kes valdasid peale laste ilmale aitamise muidki arstitarkusi või oskasid rohtusid valmistada, nagu Sibula Mari Vitsiku külast, Saveru Iti jt. Roosi Miili, Ohakvere küla ämmaemand, oli tuntud roosiarst ja nikastuste parandaja. Tema 
arstimisvõtted olid vanapärased: roosile loeti sõnu, asetati peale musta lamba villa ning seoti haige koht kinni; narile (kõõlusetupe põletik) seoti sõnade saatel ümber must lõng.

Värvikaid lugusid on räägitud Ürra Juulist, Soomest tulnud loitsijast, kehvapoolse varandusliku seisuga inimesest, kes solvamise peale võis sajatada inimesele või loomale surma ja keda kardeti, sest Juuli ütlused läksid täide.

Laulik-ravija Loviisa Mahmastol säilitas pikalt vanad kombed: asetas kapsaste istutamisel kivi peenraotsale ja varjas võõraste silmade eest leivategu. Esimesel juhul oli tegemist analoogiamaagiale toetuva uskumusega, millega loodeti saada kapsastele sama tugevad pead kui on kivi, teisel puhul välditi võõra inimese mõju leivateole. Loviisa arstis roosi ja koduloomi, kuid valdas veel ühte 20. sajandil vähem harrastatud taiga - lepitas pahuksisse läinud abielupaare. Loviisa Mahmastoli koduseks keeleks oli lapsepõlves vene keel, võimalik et osa kommetest pärines naaberkultuurist.

Uus ja vana pärimus segunesid varga otsimises, milleks kasutati kaartide panemist, vaadati varast fotolt või magnetiseeritud vee pealt. Jaan Rebane Jõhvist oli osav varga leidja, kuid ka arstimises (ravis hambavalu, sinise vihikukaane ja sõnadega roosi), lasi aadrit ning oskas vihavaenlasele sõnade ja taigadega ihuhädasid põhjustada. Pouliine Kiiver, laulik Iisaku Metskülast, jutustab oma visiidist Rebase juurde, mis on eriti kujukas selle poolest, et käiku ajendab mitte vajadus, vaid puhtakujuline inimlik uudishimu, mis leiab rahulduse.

Jõhvis elas üks mees, Rebane, ja see tegi ka vookusi, nü̈̈d on ta surnud. Ta arstis maarohtudega ja kelt miski varastati, siis tema laskis seda inimest veeklaasi vaadata - sinna tuli varga kuju, said näha, oli ta siis tuntud vai tundmata. Mina olin sellest huvitatud, läksin Jõhvi, otsisin Rebase üles. Ta majast tuli mees ja naine välja, istusid vankri ja sõitsid ära, nii ma jäingi siis üksi Rebasega. Küll ta lagi ja seinad olid täis maarohukimbusi, keiki sugu. Hakkas siis jutt käima: "Mis teil on?” - "Midagi räekimist on küll. Minu teenija sai lapse, tahan teada saada kellega, ta ise ei avalda sellest." Vastas: "Las olla tal oma teada, mis sellest ikka on." Ma nõudsin teatust. - "Kas arvate oma mehe peale?" - "Ei sugugi. Niisama tahan teada, kellega see on juhtund." - "No olgu siis peale."

Võttis kappist hariliku veeklaasi, loputas veega üle. Võttis veeämbri, tõi kaevust vee, pani klaasi, küsis minu sõrmusse, lasi kesk klaasi vee sisse. Siis küsis minu nime ja minu ema nime, tüdruku ja tüdruku ema nime. Võttis klaasi kätte, pani suu juure ja luges klaasi sisse kõvast, kõik kuulsin ise, ka emade nimed ja tütarde nimed olid hulgas. Siis pani klaasi laua peale, ise vaatas sisse vähe aega, muigas omaette naerda ja lükkas klaasi minu ette: "Vaata hästi sõrmusse sisse!” Mina vaatasin, ei 
näinud midagi. “Ära karda, vaata julgest!” Vaatasin - veike meesterahva kuju oli sõrmusse sees. Pruun pintsak seljas, näust ei tunnud. Siis küsis: "Kas tagaotsa ka tahad näha?" - "Ei hooli. Ma tahan seda paika näha, kus nad koos olid." Midagi luges ja vaatas jälle klaasi. See oli meie oma maja, keik vinnaga kaevgi õues.

Esiteks ei tahtnud hakkada. Ütlesin: "Ega sellest kohut ei tule, ma nii sama tahan rahva juttu jälgida." - Siis hakkas peale ja näitas. Maksu võttis üsna vähe, tänas. Ma sõitsin rahuliku meelega koju. See on tõeste tõsi. (KKI 31, $281<$ Iisaku khk, 1960.)

Pärimus osutab, et hüpnotisööride, silmamoondajate ja selgeltnägijate, kaarditarkade ja ennustajate visiidid tekitasid külas elevust. Hüpnoosi kasutasid vähesel määral mitmed rahvaarstid, see kuulus vahel arstimisriituse juurde, nii et haige ei osanud hiljem määrata, kas valu võtsid ära sõnad, saadud medikament või lühike hüpnootiline uni.

\section{Hundi Kustas - pärimus nõidkarjustest}

Kui rahvaarstidega seotud narratiivne pärimus on peaaegu kogu Eestis ühesugune: sarnased on nendes vahendatud arstimisvõtted, haiguste etioloogia kui ka jutud tarkadest endist, siis lood väekatest nõidkarjustest ja karjus-arstide repertuaar on idapoolsem ja slaavimõjuline. Nõidkarjuste lood ulatusid Virumaalt Tartumaale ja olid tuntud laiemal Põhja-Eesti alal. Juttude peategelasteks olid kutselised karjused, karjanõiduste valdajad, kes kutsusid välja hunte või usse, omavahelise tüli käigus saadeti metsloomad üksteise karja rüüstama.

Ka Ida-Virumaal tuntud silmamoondaja Piira Jüri oli kutselt karjus. Oma hüüdnime saanud ta oskusest joonistada kepiga mõtteline piire ümber karja enne selle juurest lahkumist. Sõnade lugemise järel ta lahkus, kuid loomad püsisid taia abil paigal ja nendega ei juhtunud õnnetusi. Meelepahahoos või kihlveo peale võis ta silme ette manada mis tahes pildi: kord olid selleks metsast hordidena välja roomavad ussid, teinekord Kuremäe teed mööda voolav vesi, mis sundis teelisi seelikuid üles tõstma, et säästa neid märjaks saamisest. Mõlemad motiivid on muistenditena üle-eestiliselt tuntud.

Suhteliselt palju jutte on talletatud Hundi Kustast, poissmehest, kellel oli pärimuse järgi hundi- ja ussivile, millega sai neid enda juurde kutsuda, ning kes suutis meelitada inimesele sisse läinud ussi välja, arstida roosi, takistada vee keema minekut, peatada verejooksu ja võtta ära vitsavalu. Seda vanapärast tarkust igaüks kasutada ei osanud. Pärimusjuttudes on Kustas õpetanud oma tarkusi neile, keda ootas peksukaristus ja mitmed on tarkuse ise proovile pannud: 
Tõin siis vitsad ja ütlesin, et tahan tunda, kas saab ilma valuta. Ta siis lõi vasaku käe pihta üks kord ja parema käe pihta kaks korda-ei olnud valus. (KKI 24, 470 (8) < Jõhvi khk, 1958.)

Pärimuse järgi ei lubanud Hundi Kustas usse tappa, põhjendades oma keeldu väitega, et igal hoonel on oma uss (ERA II 125, 111 (28) < lisaku khk, 1935). Vanemasse usundikihistusse kuulub arvamus, mille kohaselt koduhaldjas või varem majas elanud, surnud pereliikme hing võis kehastuda ussiks (Loorits 1951: 243-244). Ussi tapmine oli rangelt keelatud rahvaarstidel - ussihammustuse ravijatel - see oli seotud rahvapärase eetikakoodeksiga, samas käsitleti keeldu ka omalaadse kokkuleppena arsti ja looma vahel.

Tellimise peale ussi välja kutsunud Kustal tuli rahvajutu põhjal läbi elada pingeline olukord:

Hundi Kusta siis pobises miski oma nina ette. Ja uss tuligi. Tuli kõhe rukki õrasse sisse, õras liikus kahele puole, õras õli nisuke madal, õli näha, kuda uss ruomas kohe tierada pial. Kusta sirutas käe välja ninda ja uss keris ennast kierdu tieraja pial. Kus mehed kargasid püsti ja karjuma: "Andage nü̈̈d ussile!” - “Ärge puutuge!” kielab Kusta, "sie on minu surm, kui puudute." Aga mehed ei kuulegi Kustat, ikke vemlad ja tarikad kätte ja kisavad: "Andage ussile valu! Misse lõõrikas siin tolgendab!”

Kusta tegi kaks kõrd "kõss, kõss" ja uss pani plehku. Kusta õli pärä viel ütlend miestele: “Õleksite puutund, õleks sie minu surm õld.”

(RKM II 380, 232 < Iisaku khk, 1983.)

Koos sotsiaalmajanduslike muutustega kadus 20. sajandil vajadus täiskasvanud karjuste järele, mis põhjustas pärimuse taandumise mälestuste hulka ning rikkaliku motiivistiku hääbumise.

\section{Jakob Lobjakas - moodsate ravivõtete vahendaja}

Moodsate ravivõtete levik küladesse on ulatuslik ja esialgu pealispindselt käsitletud teema, mille tõttu teeme sissevaateid uuenduslike võtete kasutamisse juhtumipõhiselt, Julius Aleksander Reepärgi märkmete abil (vt lähemalt Kõiva 2017). Rahvaluulearhiivi kirjasaatja läbis 1931. aastal uudse ravikuuri ja kirjeldab oma päevikule tuginedes lähemalt enda ja oma kodapoolsete ravi, tema ja ravija omavahelisi vestlusi ravikuuri ajal. Neist märkmetest selguvad arstija eluseigad, kogemused ja osalt tema maailmavaade, aga ka ravija selgitused ja vaated oma patsientidele, nn rahvaarsti pärimus patsientidest (huvitavast juttude liigist on vähe materjali).

Jakob Lobjakas sõidab ravimiseks kohale Tallinnast ja peatub mõnda aega ravikuuride läbiviimiseks kohapeal. Tal on kohapeal majake, mille on kinkinud 


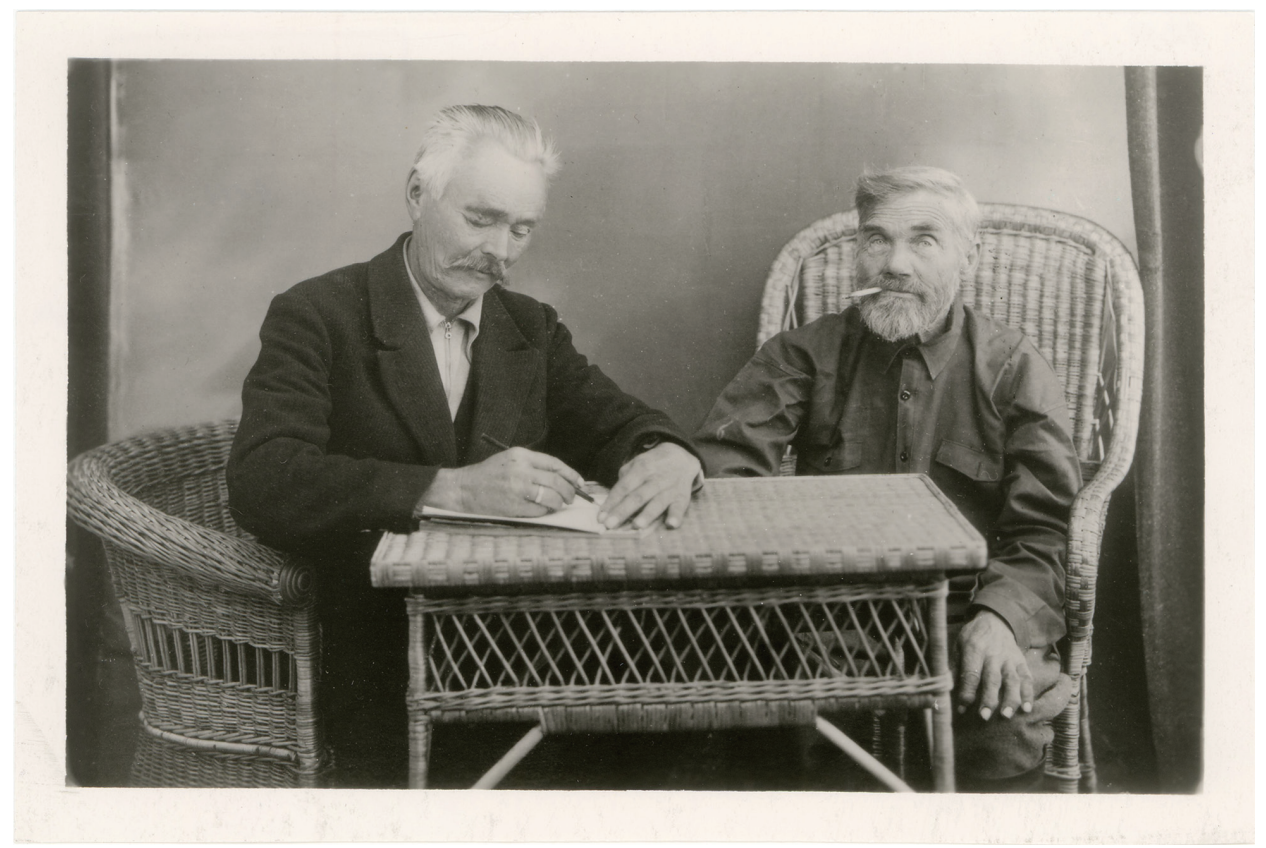

Foto 1. J. A. Reepärg kirjutab jutustaja Jaan Muruväli käest lugusid. ERA, Foto 8111.

tänulik naispatsient. Arstimisvõtetest tõuseb massaaži kõrval esile moodne nn elektriravi, mida kirjasaatja ja tema naine saavad paari nädala vältel:

Siin lähidal (Ahuaial, Sakre Marta talus) asub üks soontetriikija (soontemudija) hra Jakob Lobjakas, kes on juba umbes 80-aastane. Tema on umbes 50 aastat inimesi arstinud ja paljuid terveks teinud ja parandanud. Tema arstimise viis on "luomulik", nagu ta ise seda niiviisi nimetab. Tema otsib oma sõrmeotstega haiged kohad soontes ja kehas üles ja hakkab neid siis tubliste mudima ja hõoruma. On sooned pehmed, laseb veel elektrit kehasse. Selleks on tal väikene elektrimasin, mis ta nimetab “elektriapakraadiks". On haigus raskekujulisem, siis tarvitab peale mudimise veel mõnesuguseid vahendeid (soojad kaerakotid, soojad pudelid jne). "Loomulik" on sarnane arstimine sellepärast, et siin ei tarvitata mitte arstirohtusid, vaid aidatakse selleks kaasa, et veri kiiremini jooksma pääseks ja siis haiguse batsillid laiali kannaks. Inimese keha peab iseennast parandama.

Jätkakem päevikumärkmetega, mis kirjeldavad protseduure. Laupäeval, 17. jaanuaril 1931 on kirjasaatja märkinud üles:

Peale koolitunde käisin jällegi hra Lobjaka juures, kes tegi mulle elektrivanni. Vesi - mitmesuguste rohtudega keedetud - oli umbes $30^{\circ}$ soe. 
Olin selili vannis, ainult pea veest väljas. Ühe elektri nuia pani ta vette, teise hoidis oma käes ja oma käe kaudu laskis mulle elektrit pähe, kaela, õlgadesse jne. Ka pidasin ise teise nuia oma ihu küljes, mis siis muidugi sel ajal veest väljas oli. Vees viibides tundus elektri tõmbus olema hoopis tugevam kui muidu. Olin vees umbes 20 minutit, siis jooksis vesi ka näost alla. Kui selle järele voodi teki alla pugesin, kus mind edasi arstiti, jooksis kehast veel tükk aega vett. - See oli vast "saun", mis ma ennem pole saanud! Lubas mulle veel ühe niisuguse teha. (ERA II 197, 427/31 $<$ Haljala khk, 1938.)

Raviseansside ajal töötas Reepärg Kavastus kooliõpetajana ja elas koolimajas. Lobjakat nimetab ta enne seansside algust "lähidal (Ahuaial Sakre Marta talus) asub üks soontetriikija (soontemudija)", kes raskemate haiguste juures kasutab mõnesuguseid lisavahendeid: soojad kaerakotid, soojad pudelid jm. Ravija elukäigust selgub, et tal on olnud kokkupuuteid meditsiiniga, kuid enamiku elust on ta tegutsenud muudel aladel ning vanemas eas naasnud ravimise juurde. Lobjakas olnud kroonuteenistuse ajal Peterburis velskriks ja hiljem kaubelnud rändkaupmehena arstirohtudega maal ringi liikudes. Elu jooksul on ta pidanud kauplust, teinud müüritööd ja pidanud muid ameteid. Tema haiguse-tervise diskursus on omapärane, see sisaldab vanu ja uusi seletusmudeleid: näiteks veendumus, et kui inimese veri panna kiiremini voolama südame ja soonte parema töötamise tagajärjel, siis liiguvad "haiguse pisielukad" haigest kohast eemale. Selle kõige saavutamiseks on oluline massaaž ja enesemassaaž käepäraste vahendite abil. Haigusi seletab ta veel nn kondi otstesse koguneva limasarnase ainega, mis lubjastudes põhjustab vaevusi ja mida ta suudab hõõrumisega puhastada. Rahvapärase vesi-ja elektriravi rakendamine kuulub sajandialguse moetrendide sekka.

\section{Viilip Klaas - muusikamees ja haridusliikumise entusiast}

Jakob Hurda kaastööline Viilip Klaas (22. okt. 1857 - 20. mai 1917) oli rätsep, rahvaarst, luuletaja, muusikamees ja haridusliikumise entusiast. Tema elulugu iseloomustab eestlastest ametimeeste ja perekondade liikuvat eluviisi, samuti nende kirjandus- ja muusikaharrastusi ning uuendusi, mida sellised inimesed külakogukonda tõid.

Perekonnaloost saame teada, et Haljala kihelkonna Kavastu kogukonna Kõldu külas alguses talusulasena, hiljem rätsepana töötanud Jaani (1768-1837) kahest pojast said samuti rätsepad, rätsep Rein ja rätsep Ants, kes elasid küla serval kõrvutiasuvates väikestes majades. Rätsep Rein (1809-1867) pani esimesena ümbruskonnas oma majale ette klaasitud aknad, mispärast kohalikud elanikud hakkasid teda naabrist eristamiseks nimetama klaasirätsepaks. 


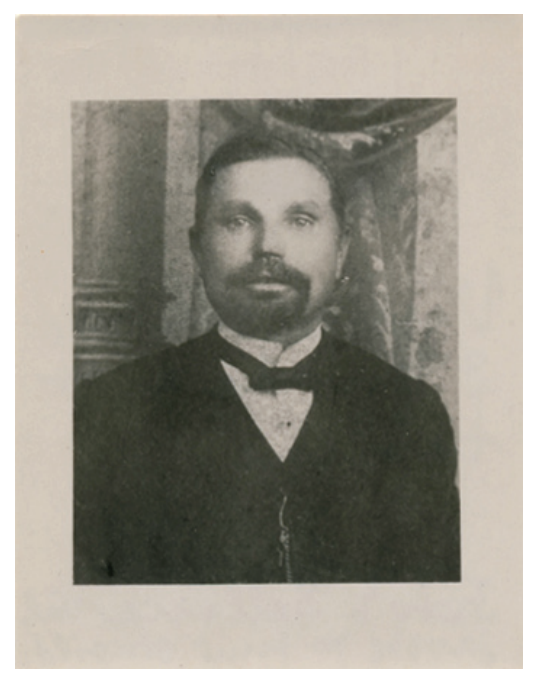

Foto 2. Viilip Klaas, rahvaluulekorjaja. Ed. Selleke väljavõte ja suurendus (u 1/2 korda). J. A. Rehbergi saadetud grupipildist. ERA, Foto 1226.

Perekonnanimede andmise ajal sai/võttis kogu suguvõsa endale pärisnimeks Klaas.

Rahvaluulearhiivi saadetud andmestikust selgub, et rätsep Reinu ja tema naise Miina (snd 1824) viienda lapsena sündis 22. oktoobril 1857. aastal poeg Viilip, kes oli mõisakirjas 1857. ja 1866. aastal Philipp ning nooremas eas kasutas ka ise ametlikku nime. Rein Klaas suri nakkushaigusse, kui poeg Viilip oli kümneaastane.

1976. aastal laekus rahvaluulearhiivi Viilip Klaasi tegevuse kohta pikem kokkuvõte ühekülamees Harald Kadarilt, kelle kirjatööst on nopitud järgmisi fakte rätsep-ravija elukäigust (RKM II 321, 154/66 < Haljala khk, 1976). Viilip oli noorelt muusikahuvidega, õppis noodist mängima ning käis lähedastes metsades pasunapuhumist harjutamas:

Noodi seadis ta madalatele puuokstele ja asus ise põlvili olles tuututama. Viilipi kodu juurest mööda viis tee külast postmaanteele välja. Ühel pühapäevahommikul olnud Viilip samas salus pillipuhumisega ametis, kui kirikusse tõttavad külanaised temast mööda minnes teda teretanud. Pillimees aga ei pannud ümbrust tähelegi. Pea levis külas kuuldus, et hull olevat olnud metsas, ise põlvili puu ees maas ja puhunud pasunat.

Viilip kolis ema ja õega varsti pärast seda juhtumit kümneks aastaks Kose kihelkonda vanema venna Jaani juurde, omandas seal rätsepakutse ja abiellus. Naise ja lapse surma järel kolis Viilip esmalt tagasi kodukülasse, kuid rändas sealt edasi Krimmi vend Peetri juurde. Pärast haigestumist pöördus ta Krimmist tagasi sünnikohta ning asus taas rätsepana elatist teenima. Rätsepaameti kõrval oli Viilip Klaas abivalmis ja hinnatud külatohter, kes ravis haigeid vee, veeauru, mähiste ja maarohtudega. Taimedest kasutas ta kummelit ja tegi kummelikompresse, kasutas kuumade kaerte kotti kopsupõletiku vastu, näsiniinekoore kompresse villihaiguse (kasvaja ja mitme muu raske haiguse toonane rahvapärane nimetus) vastu. Peale päritud põlise vanarahvatarkuse sai ta arstimise alaseid teadmisi trükistest.

Viilipi hoiakuid iseloomustab asjaolu, et ta ei söönud sealiha ega rasvarikkaid toite, vaid eelistas taimetoite. Arstimise eest saanud ta ühelt ravialuselt Kõldu külla majaaseme, kuhu ehitas väikese elumaja. Enamasti piirdus tema tasu või ja piimaga. 
Viilip Klaasi luulekatsetused on jõudnud samuti rahvaluulearhiivi, kuid veel märkimisväärsem on muusikaharrastus. Teadaolevalt on ta koostanud raamatu viiekümne noodikirjas pillilooga, õpetanud noortele pillimängu ja noodikirja, mis aitas mõne noormehe sõjaväeteenistuses orkestrandi leivale. Vanemas eas käinud Viilip Klaas külapidudel viiulit mängimas ja kandnud taludes käies alati taskus puust plokkflööti, millega ta armastas musitseerida. Ta on juhatanud Kavastus laulukoori, loonud harrastajate näidenditele viise, õpetanud laulusid ja olnud ka näitejuht.

Viilip Klaas suri 20. mail 1917. aastal. Järgnev sündmustik sarnaneb äravahetamiseni klassikalise rahvajutumotiiviga, ent olevat tõde, mitte fiktsioon ja fantaasia. Oma maja pärandas ta ristipojale, vana kasuka aga heale tuttavale, kohalikule saunikule, sooviga, et uus omanik kasukat hoolega hoiaks. Selle soovi mõtet taibati liiga hilja. Kasukanäru oli siis juba kaltsukaupmehele (rändkaupmees, kes müütas Võõpsust toodud potte, ostis kokku riideräbalaid ning viis need Räpina paberivabrikusse) ära antud. Viilup hoidnud oma kulda kasuka sisse õmmeldult. Kaltsukaupmeest otsiti tulutult taga.

\section{Allika Ella - ema tarkuste vahendaja}

Ella Asnaurjani jutustuste vahendusel saame osa taimetarga, inimeste ja loomaderavija tarkustest. Pärimusliku ravijateliini esindajana on tal meeles vanemad võtted, emaema tarkused:

Nuorelt mul kõht tihti valutas, ema õpetas: "Hakka vuodi, käed aja laiali nigu rist, jalad siruta ka laiali kahele puole!" Mina sirutasin. Ema hakkas mõotama käega pahema jala suurest varbast peale parema käe pikkpietrini välja, siis parema jala suurest varbast piale vasema käe pikkpietrini välja. Ninda risti mõotas kolm korda. Tema kätel oli võimu. (RKM II 330, $242(29)<$ Iisaku khk, 1983.)

E. Asnaurjani - kohapeal tuntud Allika Ellana - ema oli vaksaga mõõtnud karu jäljed ja lahutanud kolmed vainuköied. Pärimuse kohaselt andis vainuköie lahutamine kätele arstimisvõime. Lapse (täiskasvanu) mõõtmine on rahvusvaheliselt tuntud vanem ravivõte.

Arstimistarkusi tundis ka Ella õde Alma:

Aga siis meie Alma hakkas ise rohtu kietama, kietas kumelid ja põldosjasid, viis minutit kietas. Jahutas selle kiedusse ära, selle sisse torkas haige käe, hoidas sies, ma ei tia kui kaua. Ninda tegivad kolm päeva. Siis pullistas selle haige kuha käe pial ülesse kõrgele ninda. Kui siis teine (Alma vist) kahmas sellest pullistusest sõrmedega kinni, rapsas korraga välja. Oli niisuke kasvaja: haruline, üeksma haruga oli, nigu ma mäletan. 
Käsi sai tervest, mõjale ka ei hakkand kasvama. (RKM II 380, 221/2 (29) < Iisaku khk, 1983.)

Ella vanaema tundis taimravi ja ta osanud koguni vasikal krampe arstida, liikmeid paigale panna, ent ei õpetanud oma teadmisi edasi, vaid pidas neid saladuses. Tütretütre sõnutsi oli vanaemal nn mongasilm ehk kuri silm, millega ta põhjustas kahju inimestele ja loomadele (KKI 24, 130 (9) < Iisaku khk, 1957). See ei takistanud inimesi vähimalgi määral haiguste korral temalt abi otsimast.

1957. ja 1958. aastal Kirde-Eestis rahvaluulet kogudes puutusid mitmed folkloristid Ellaga kokku. Põhjuseks polnud tema vanaema ega ema kohta teadete otsimine, vaid asjaolu, et tegemist oli harukordse pärimuste tundjaga. Tookord lindistati Ellalt üle poolesaja kohaliku jutu, samuti laule. Hiljem lisandus üht-teist tema enda poolt kirjapanduna. Folklorist Richard Viidalepp iseloomustab teda kannatliku ja hea jutustajana. Muu hulgas saadi teada, et Allika Ella ennustab käejoonte ja kaartide järgi. Ise kõneles ta oma andest nii:

Rahvast käis palju, kaugelt ikke tulivad, Slantsõst käis üks naine. Nunnad saatsid, et mene kuule, mis ta räägib sulle. Mul on niisuke telepaatia võime, ei tia kas praegu on, enne oli küll. Rääkida võib inimesele mitut muodi, aga miski minus sunnib kohe ühtmuodi rääkima. Enne kui ennustama hakkad, ajad võõra inimesega juttu, näed ju kohe, mis inimene ta on, mis ta luodab ja tahab. (RKM II 330, 213 (21) < Iisaku khk, 1982.)

Hinnatav on teinegi iseloomustus oma ande kohta:

Mina arvan, et maa sies on niisugused jõud, nied annavad edasi nigu raadio vai. Kivil on sies külgetõmbe jõud, kivi andas mulle edasi. Mina seisasin kivi juures. (RKM II 380, 242 (29) < Iisaku khk, 1983.)

Viimane seletus on iseloomulik 20. sajandi teise poole arstijatele ja imepäraste võimetega isikutele, kes sagedasti seovad oma tajusid ning teadmisi loodusest lähtuvate signaalide ja mõjudega. Ella Asnaurjan on pärimusteadete järgi ka ise arstinud. Näeme, et ühes perekonnas realiseerusid võimed sugupõlvede jooksul küllalt lahknevates suundades.

Uskumuste järgi polnud arstikutse sugugi kerge, vaid tõi endaga kaasa keeruka saatuse ja kannatusi vanaduses. Võimed kadusid pärimusekandjate arvates hammastest ilma jäämisel ja tervise halvenemisel. Ainult täiesti terve ja elujõuline inimene võis edukalt teisi arstida ja abistada.

\section{Kokkuvõte}

Kas loitsud on tavalised poeetilised tekstid? - Ei ole. Nende juures on esmaoluline praktiline eesmärk, mis koos usundilise alusega mõjutab sõnakasutust. 
Loitsude keskmes olid varem inimeste ja vaimumaailma suhted, olulise rõhuga inimeste ja lähiümbruse suhetel, kuid põhiliseks funktsiooniks oli ja jäi sõnamaagiliste rituaalidega tervendamine, igapäevase elu stabiliseerimine. Arstimissõnad käibisid vormiliselt kireva ja varieeruva kogumina: kasutati palvete, piibli ja lauluraamatu autoriteeti, allusioonidel ja müütilisel maailmapildil põhinevaid tekste, haiguse ümbersuunamisi ja tagasisaatmist. Ühe piirkonna näitel eendub kontaktkultuuride ja konfessioonide mõju traditsioonile, suulise ja kirjaliku traditsiooni põimumine ning seosed sõnamaagiaga.

Viimase saja aasta jooksul on rahvameditsiini võttestikku integreeritud teadmisi erinevatest koolkondadest, tähtsustusid alternatiiv- ja komplementaarmeditsiini suunad (jooga, hiina meditsiin, ajurveeda, muusikateraapia jm), millest enamik on kosmopoliitsed suunad. Seega saame üldistada, et kosmopoliitse meditsiini kõrvale on astunud kosmopoliitne rahvameditsiin. Teise olulise suunana eendub kohaliku rahvameditsiini tähtsustamine, mis rõhutab põlisväärtusi ja loob kultuurilisi uustõlgendusi. Muutuste iseloomustamiseks on vaadeldud erineva spetsialiseerumisega ravijaid poolmüütilistest nõidkarjustest kohaliku kultuuri uuendajateni, kelle kõrvalamet oli ravimine. Ühtlasi ilmneb nende osa jututraditsiooni loomisel ja edasikandmisel ning oskus siduda elukäiguga folkloorseid jutumotiive.

\section{Tänuavaldus}

Artikkel on valminud uurimisprojektide IUT 22-5 "Folkloori narratiivsed ja usundilised aspektid”, EKKM14-389 “Müüdilise pärimuse monumentaalväljaanded" ja Eesti-uuringute Tippkeskuse (TK-145 CEES) toetusel. Autor tänab Mall Hiiemäed ja anonüümseid retsensente asjakohaste märkuste eest.

\section{Arhiivilühendid}

E - Matthias Johann Eiseni rahvaluulekogu

ERA - Eesti Rahvaluule Arhiivi kogu

E, StK - M. J. Eiseni stipendiaatide kogu

EÜS - Eesti Üliõpilaste Seltsi rahvaluulekogu

$\mathrm{H}$ - Jakob Hurda rahvaluulekogu

KKI - Keele ja Kirjanduse Instituudi rahvaluulekogu

RKM - Riikliku Kirjandusmuuseumi Rahvaluule osakonna kogu 


\section{Kirjandus}

Crystal, David 1987. The Cambridge Encyclopedia of Language. Cambridge [Cambridgeshire] \& New York: Cambridge University Press.

Cunningham, Graham 1999. Religion and Magic: Approaches and Theories. Edinburgh: Edinburgh University Press.

Cunningham, Graham 2007 [1997]. Deliver me from evil: Mesopotamian incantations, 2500-1500 BC. Studia Pohl (Series Major). Roma: Pontificio Istituto Biblico.

Dunn, Frederik L. 1976. Traditional Asian Medicine and Cosmopolitan Medicine as Adaptive Systems. Leslie, Charles M. (toim). Asian Medical Systems: A Comparative Study. Berkeley: University of California Press, lk 133-158.

Eisen, Matthias Johann 1896. Seitse Moosese raamatut. Katse kuuenda ja seitsmenda Moosese raamatu seletuseks. Tallinn: K. Busch.

Harper, Donald 1997. Early Chinese Medical Literature. The Mawangdui Medical Manuscripts. The Sir Henry Wellcome Series (Book 2). London: Routledge.

HDA = Hoffmann-Krayer, Eduard \& Bächtold-Stäubli, Hanns 1927-1942. Handwörterbuch des deutschen Aberglaubens, IV, VII. Berlin und Leipzig: W. de Gruyter.

Hiiemäe, Reet 1997. Eesti katkupärimus. Monumenta Estoniae Antiquae II. Eesti muistendid. Mütoloogilised haigused I. Tartu: Eesti Keele Instituut.

Jõhvi, Mare 2009. Jõhvi Mare: eks ma olen kiiksuga. Anne \& Stiil. Õhtuleht 1. oktoober (http://annestiil.ohtuleht.ee/647073/johvi-mare-eks-ma-olen-kiiksuga - 5. juuli 2017).

Kivari, Kristel 2016. Dowsing as a link between natural and supernatural. Folkloristic reflections on Earth radiation and dowsing practice. Doktoritöö, Tartu Ülikool. Tartu: Tartu Ülikooli Kirjastus.

Kongla Ann 2006 = Maavalla Koda. Kodulehekülg (https://www.maavald.ee/koda/ usuvabadus/yldist/1102-kongla-ann - 5. juuli 2017).

Korb, Anu 2006. Ravitsemisoskus kui pärimusrühma ühisteadmus: Siberi Rõžkovo küla näide. Mäetagused 34, lk 87-110 (http://www.folklore.ee/tagused/nr34/korb.pdf - 5. juuli 2017, doi: 10.7592/MT2006.34.korb).

Kreutzwald, Friedrich Reinhold \& Neus, Heinrich 1854. Mythische und magische Lieder der Ehsten. Leipzig: Leopold Voss.

Krohn, Kaarle 1924. Magische Ursprungsrunen der Finnen. Folklore Fellows Communications 52. Kerava: SKS.

Kues ja seitsmes Mosese Raamat 1872. Rakvere: L. Oppermann.

6. ja 7. Moosese raamat 1914. 6. ja 7. Moosese raamat: See on Moosese magikline waimude kunst, kõikide saladuste saladus. Sõna-sõnalt wana käsikirja järele. Tallinn: Tulevik.

Kõiva, Mare 1989. Aleksei Lesest ehk Tiitsu Seiust. Hiiemäe, Mall (toim). Paar sammukest eesti kirjanduse uurimise teed XII. Jakob Hurda 150. sünniaastapäevaks. Tallinn: Eesti Raamat, lk 80-100.

Kõiva 1990 = Kõiva, Mare 1990. Estonskije zagovory. Klassifikatsija i zhanrovye osobennosti. Dissertatsija. Tallinn. Rukopis. 
Kõiva, Mare 1992. Loitsud ja rahvaarstid. Rüütel, Ingrid (toim). Ida-Virumaa rahvakultuurist. Tallinn: Infotrükk.

Kõiva, Mare 1996. The transmission of knowledge among Estonian Witch Doctors. Folklore: Electronic Journal of Folklore 2 (http://www.folklore.ee/folklore/vol2/docdoc. htm - 7. juuli 2017; doi: 10.7592/FEJF1996.02.docdoc).

Kõiva, Mare 1998. Palindromes and Letter Formulae: Some Reconsiderations. Folklore: Electronic Journal of Folklore 8 (http://www.folklore.ee/folklore/vol8/mare.htm - 7. juuli 2017; doi: 10.7592/FEJF1998.08.mare).

Kõiva, Mare 2011a. Eesti loitsud. Tallinn: Pegasus.

Kõiva, Mare 2011b. Multilinguality and Code Change in Incantations. Congressus XI Internationalis fenno-Ugristarum. Pars VII. Dissertationes sectionum et symposiorum ad ethnologiam, folkloristicam et mythologiam. Pilisscaba 2010, 1k 84-90.

Kõiva, Mare 2011c. Koldovskie, magicheskie i zagovornõje knigi v estonskom folklore. Tsentr i periferia 3, lk 69-75.

Kõiva, Mare 2013. Loitsud ja rahvaarstid. Rüütel, Ingrid (toim). Ida-Virumaa rahvakultuurist, 2. parandatud ja täiendatud trükk. Rakvere-Tartu: Viru Instituut, lk 175-196.

Kõiva, Mare 2017. Loitsude värvimaailm. Tartu [käsikiri].

Levón, Kaarlo 1904. Tutkimuksia loitsurunojen alalla: verensulkusanat ja raudan sanat. Tampere [Akatemiallinen väitöskirja].

Lill, Ene 2017. Energiakanalid - pärimus, teadus ja Vana-Eesti massaaž. Harmoonikum 3. märts (http://harmoonikum.ee/energiakanalid-parimus-teadus-ja-vana-eesti-massaaz/7. juuli 2017).

Loorits, Oskar 1931. Eesti-liivi kalurite sõnakeeld ja salakeel. Virittäjä 35:4, lk 447-468.

Loorits, Oskar 1932. Estnische Volksdichtung und Mythologie. Tartu: Akadeemiline Kooperatiiv.

Loorits, Oskar 1951. Grundzüge des estnischen Volksglaubens 2. Skrifter Utgivna av Kungl. Gustav Adolfs Akademien för Folklivsforskning 18:2. Lund: Carl Blom.

Mencej, Mirjam 2001. Gospodar volklov v slovanski mitologiji. Županičeva knjižnica 6. Ljubljana: Oddelek za etnologijo in kulturno antropologijo, Filosofska fakulteta.

Must piibel 1994 = Must piibel: VI ja VII Moosese raamat. Salaretseptid ja maagia. Tallinn: Force Majeure.

Põldmäe, Rudolf 1938. Die früheste Verbreitung der Himmelsbriefe in Estland. Acta Ethnologica 3, 2/3, lk 100-115.

Tan, Michael Lim 1989. Traditional or transitional medical systems? Pharmacotherapy as a case for analysis. Social Science \& Medicine 29 (3), lk 301-307.

Uuspuu, Villem 1938a. Eesti nõiasõnade usulisest iseloomust. Usuteadusline Ajakiri, lk 15-24.

Uuspuu, Villem 1938b. Nõiaprotsesse Pärnu maakohtu arhiivist kuni 1642. Usuteadusline Ajakiri, lk 114-126.

Vaitkevičienè, Daiva 2008. Lietuvių užkalbèjimai: gydymo formulès / Lithuanian Verbal Healing Charms. Vilnius: Lietuvių Literatūros ir Tautosakos Institutas. 
VanArsdale, Daniel 1998-2007. Chain Letter Evolution (http://www.silcom.com/ barnowl/ chain-letter/evolution.html - 7. juuli 2017).

Wheelock, Wade T. 1987. Sacred Language. Eliade, Mircea (toim). Encyclopedia of Religion 8. New York \& London: Macmillan, lk 439-446.

Yamauchi, Edwin M. 2005. Mandaic Incantation Texts. New York: Gorgias Press LLC.

Mare Kõiva - Eesti Kirjandusmuuseumi folkloristika osakonna vanemteadur. Folklooriajakirjade Folklore: EJF ja Mäetagused peatoimetaja, paljude usundi- ja folkloorikogumike toimetaja.

mare@folklore.ee

\section{Summary}

\section{Healers and charms in Virumaa}

\section{Mare Kõiva}

Keywords: alternative medicine, book of magic, charm, cosmopolitan folk medicine, folk medicine, healer, healing charms, oral and written lore, Virumaa

On the basis of Virumaa material, the article discusses healing words as well as charms that were used to regulate communication between human beings and the world of spirits. Healing words richly varied in form made use of fragments of prayers, Bible texts, and hymnals, and were based on legend material, allusions, and mythic worldview. The article gives an overview of a) the relationship between oral and written lore in charm tradition, connections with fictional and real books of wisdom; b) exchange of language codes; c) regulations of word-magic behaviour; d) healing charms and charms regulating social relations, housekeeping, and humans' relationship with nature.

The second half of the article discusses changes in healers' healing tradition. During the past century, folk medicine integrated knowledge from different schools, and the importance of alternative and complementary medicine, such as yoga, Chinese medicine, Ayurveda, and music therapy (most of these cosmopolitan), increased. So we can conclude that cosmopolitan folk medicine exists side by side with official medicine. Another significant trend rising to the fore highlights the importance of local folk medicine, which emphasises traditional values and creates novel cultural interpretations. To characterise the changes, the article introduces four healers, ranging from a half-mythic witch-herder to the healers-innovators of medical methods and local culture.

Mare Kõiva is Senior Research Fellow of the Department of Folkloristics at the Estonian Literary Museum; editor-in-chief of journals of folklore Mäetagused and Folklore: Electronic Journal of Folklore; editor of a number of collections on folk belief and folklore.

mare@folklore.ee 